University of Louisville

ThinkIR: The University of Louisville's Institutional Repository

Electronic Theses and Dissertations

6-1943

\title{
Adoption procedures and practices in Jefferson County, Kentucky,
} 1941.

Ruby Arnold Dennis

University of Louisville

Follow this and additional works at: https://ir.library.louisville.edu/etd

Part of the Social Welfare Commons

\section{Recommended Citation}

Dennis, Ruby Arnold, "Adoption procedures and practices in Jefferson County, Kentucky, 1941." (1943). Electronic Theses and Dissertations. Paper 1889.

https://doi.org/10.18297/etd/1889

This Master's Thesis is brought to you for free and open access by ThinkIR: The University of Louisville's Institutional Repository. It has been accepted for inclusion in Electronic Theses and Dissertations by an authorized administrator of ThinkIR: The University of Louisville's Institutional Repository. This title appears here courtesy of the author, who has retained all other copyrights. For more information, please contact thinkir@louisville.edu. 
UNIVHRSITY OT LOUISVIIIE

ADOPTION PROCEDURES AND PRACTICRS IN

JHITIRESON COUNTY, KIINTUCKY, 1941

\author{
A Dissertation \\ Subuitted to The Faculty \\ of The Graduate Sehool of The UnIrersity of Loulsville \\ In Partial Fulfilment of The \\ Requirements for The Degree \\ of Master of Solence in Social Administration
}

Division of Social Administration

By

Ruby Arnold Dennis 
NAME or STUDENT: Ruby Arnold Dennis

TITLE OF THESIS: Adopt1on Procedures and Pract10es

in Jefferson County, Kentucky, 1941

APPROVID BY RFADTNG COMATTTER COMPCSTD OF THE

FOLCONIITG MEMBERS:

John J. Cronin

Lois Blakey

Robert I. Kutak

NANEC OF DIRECTOR: John J. Cronin

DAITs: June 5, 1943 


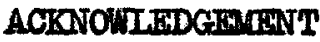

Without the permission, cooperation and assistance of Miss Elizabeth Fike, Director of the Child Welfare Division of the Kentucky Department of Welfare, this study would not have been possible.

I gratefully acknowledge my indebtedness to Mr. John J. Cronin, who supervised me in the research project which is the besis of this dissertation. 
ADOPIION PROCEDURTS AND PRACTICES IN

JEITIERSON COUNTY, KANNTUCKI, 1941 
TABIFT OT CONTEANIS

Page

LIST or TABLRS ....................... ti

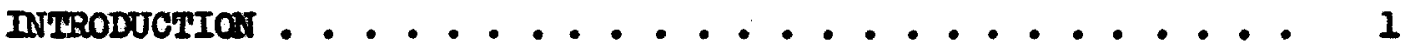

Chapter

I. PERTINUHIT ASPICTS OF THE PROBLIG OF ADOPTICR . . . 5

II. THE MATURAL PARIETTS ............ 34

III. THR CANDIDATH TOR ADOPTION ........... 54

IV. THE ADOPTIVE PARTIVIS ........... 96

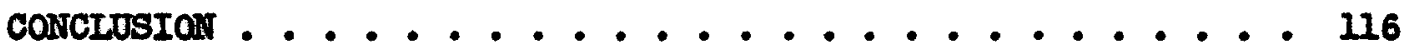

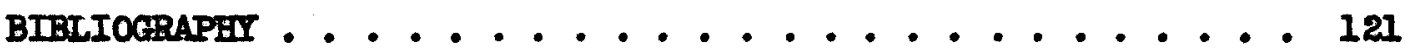

Appendix

I. COPY OF ADOPTION LAII ENACTED JUNTE, $1940 \ldots 127$

II. OUTLONE FOR CONFIDIANTIAL RERPORT TOR THE USE

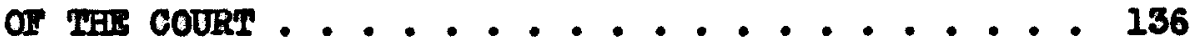

III. ADOPTION YATERRIAL (OUTITIR USIED FOR STUDY OF

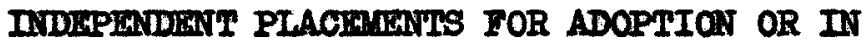
PLACTMIYYTSS HOT YADE BY A CHIID-PLACTNG AGERTCY WITH AN APPROVED CASHWORKK PROGRAN) . . . 139

IV. OUTHTITE TOR RRESTRARCH ............ 144 
ITST OF TABIES

Table

Page

1. Age of Mother by Marital Status at Time of Chlld's Blrth................... 42

2. Natural Parents' Reasons for Relinqui shmont of Child for Adopti on by Status of Child at Blrth.................... 46

3. Marital Status of Natural Parents at Time of Adoption by Status of Child at Birth Born In Wedlook

4. Marital Status of Natural Parents at Time of Adoption by Status of Child at Birth Borm out of Wedlock

5. Children Adopted in Jefferson County, by Race and per 10,000 Population ...........

6. Sex of Children Adopted, by Relationship or Petitioner to the child ................

7. Age of Child at Adoption, by Status of Child at Birth ....................

8. Children Born Out of Wedlock, With or Without Benerit of Ageney Planning, by Blrthplace....... 62

9. Iength of Time Child Ilved in Adoptive Home Prior to Granting of Adoption .............

10. Age of Child at Time of Placement in Adoptite Home, by Status of Birth and Type of Placement. . . . 74

11. Persons or Agency Giring Consent for Adoption . . . . 82

12. Perlod of Residence of Child in Adoptite Home Prior to Grant of Adoption Decree, by Relationship of Child to Adoptive Parents ......

13. Status of Child at Birth, by Relationship of Petitioner to Child.............. 101

14. Relationship of Adoptive Parents to Child ....... 102

15. Age of Adoptive Mother, by Relationship to the Adopted Chlld . . . . . . . . . . . . . 104 


\section{LIST OF TABLES - (Continued)}

Table

16. Ixtent of Formal Iducation of Adoptire Parents by Relat lonship of the Parents to the Adopted Child ................ 109

17. Number of Persons in the Adoptive Family by Relationship of Child to Aloptire Parents ...... 110

18. Annual Income in Adopt1 vo Homes ........... 111

19. Adoptive Parents' Motires for Adoption ........ 113

20. Duration of Married Life Prior to ChildPlacement in Adoptite Home ............. 114 
DNTRODUCTION 


\section{INTRODUCTION}

This study is an attempt to evaluate the procedure employed in the adoption of children in Kentucky since the enactment of the now adoption law in June, 1940, which made mandatory a social investigation during the sixty-day period required between the date of the 1 iling of the petition and the date of the court hearing. It aims (I) to examine the operations of the Kentucky law in the area of Jefferson County for which the records were made avallable by the State Department of Nelfare, Child Welfare Division, Frankfort, Kontucky, and (2) to measure the local procedure by the standard of the best arailable knowledge and practice.

In the process of exemination and measurement of $100 a l$ procedure, it is well to bear in mind that (1) many of the adoptions studied were begun a number of years ago, without benefit of specialized adoptire-plecing techniques, (2) the adoption law requiring social inrestigation is new and (3) the machinery set up for its administration has not been in operation long enough for us to evaluate its program of interpretation to the community. The community will get the kind of service in the field of adoption which it demands. For the information of those interested in the development of improved adoption practices for all candidates for adoption, this study will point out certain adverse aspects from whlch we may devlate in the future for the Improvement and development of better standarde in adoption as related to the child welfare of this community and tho state. 
The materials in this study are (I) seventy-five Confidential Reports for the Use of the Court at the time of the adoption hearings which furnished the basis for the required approval of the adoption by the State Department of Nelfare and (2) pertinent 11terature on thoory and practice of adoption.

The method of this study was to examine the participants chiefly concerned in the adoption procedure. They are the natural parents, the candidate for adoption and the adoptive parents. These are studied in terms of (1) atandard procedure and (2) local cases and local procedure.

The three chapters analjzing these three participants in turn are preceded by a chapter entitled Pertinent Aspects of the Adoption Problem, giving necessary background for this analysis in terms of the (1) movement in adoption procedure and (2) the now Kentucis law of 1940 .

Jefferson County, one of one hundred twenty (120) counties in the state, was selected for the area of the study because it included a large urban community, small unincorporated comunities and some distinctly rural areas. In Jefferson County child-placing is being done by both public and private caseworking agencies, and by religious Institutions engaged in the eare of dependent children. Jefferson County contains the largest clty in the state, Loulsille, with a population of 319,077 . The total county population is 385,392 , a little 1ess than one-seventh of the population of the entire state, which is

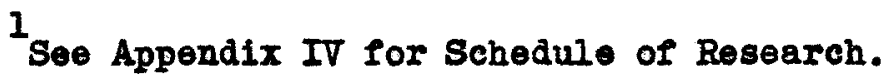


1

2,845,627. Since more children are adopted in urben areas then in 2

rural areas, we can expect from this county contalning the largest city in the state a fairly representative picture of adoption procedures throughout the state.

The serenty-five Confidential Reports for the Use of the Court included each adoption flled and completed in Jefferson County in 1941, plus eleven adoptions which were filed in 1940 but not completed unt1l 1941 and six adoptions which were filed late in 1941 but com3

pleted in 1942. For purposes of research, one adoption during 1941 was not included because of the lack of information, ordinarily found In a report for the use of the court.

1

Sixteenth Census of the U. S., U. S. Dept. of Comerce, Table 22 (Washington, D. C.: U. S. Government Printing off1ce, 1940).

ZMary Buth Colby, Problems and Procedures in Adoption, U. S. Children's Bureau \#262 (Mashington, D. C.: U. S. Governnent Printing Office, 1941), p. 4 .

${ }^{3}$ Consent to read these reports was given by Miss Ml1zabeth Fike, Director of the Child Welfare Division, Frankfort, Ky. 
CHAPIER I

PERTINIRNT ASPECTS OF THE ADOPTION PROBLIM 
CHAPTER I

PERTINANT ASPECIS OF THE ADOPTION PROBLAM

The practice of adoption was sanctioned by early c1filizations as a mothod of caring for chlldren. However, it was nover accepted as part of the ccmon law of Ingland and so could not become the practice In this country without statutory provision. The first adoption law in this country was passed in Massachusetts in 1851 and, I1ke early statutes in other states, put emphasis on the rights of inheritance and the legal privileges involved, Instead of upon the social aspects of the relationship. 1

At I1rst, adoption was a method by which a family without an heir might secure an heir to succeed to the property rights for which nature made no provision. It was a procedure by which a natural father, whose claim to his child was not unlike the claim an owner had to an Inanimate object that was the subject of property rights, might permenently divest himself of those rights and transfer them to the adopting parent.

According to the best standards in current adoptive practice 1t is generally accepted that whenever the custody of a helpless child is transferred from one person to another, there should not only be sone final and authoritative action, giving the child security, but all possible care should bo taken to insure satisfactory adjustment of 1941, pp. 97-98. 
the child and the new home to each other. Actually this is not always possible unless there is an antecedent investigation or social study and later a trial period of the child in the hame under supervision. The laws of Kansas, Indiana, Louisiana, Maine and Vemont now provide for supervision in the home during the residence period.

The fact that in Kentucky an improved adoption law was enected In 1940 gave eridence that certain interested persons and the legislature were aware of the need for improved practice in adoption. Since the individuals wishing to give child for adoption and those taking a child for adoption are weighted heavily by the emotions inrolved, it is well to have adequate legislation to protect the child who is unable to speak for himself in plans which so ritally affect him and his future happiness. We are concerned with protective legislation because adoption more often involves an infant or young child rather than an adult. Too, more often the candidate for adoption is of illogitimate birth and the mother, in order to protect her original status in the community, is moved to do something, without benefit of a calm thinking through of the situation.

Statistics substantiate the statement that adoption has become an approved solution of the problem of children born out of wedlock, and Miss Ellzabeth Jones Includes another group for similar solution, that of children whose family status is unfortunate because of

1

Ilizabeth N. Jones, "Adoption Law in Cook County, Illinois", The Social Service Reriew, (Chicago, Ill., Vol. XI, No. 4, Dec. 1937).

${ }^{2}$ Colby, Problems and Procedures in Adoption, op. cit., p. 69.

3hite House Conference, Dependent and Neglected Children

(New Yorik: D. Appleton - Century Co., 1933), p. 267. 
1

parental neglect. In 1929 in Massachusetts, six hundred thirty-nine (639) illegitimates camposed the larger group in one thousand forty $(1,040)$ children adopted that year. The Cleveland Conference on $1110-$ gitimacy found the same large proportion. In conclusion, the White House Conference Comittee on the Soclelly Handicapped: Dependency and Neglect, stated adoption should be considered only one of many solutions for the illegitimate ch1ld. In general, if the child is not wanted by his mother after a reasonable perlod and has no sultablo relatives, he will be happier in a permenent foster family home. It was recomended that no legal action be taken until after a trial pe3

riod of six months to a year.

Recognizing that certain children are not good adoptive risks, because of jeopardizing heredity backgrounds, mental defect, and physical handicaps, it is imperative thet the modern contributions of medieine, paychiatry, psychology and social work be made aveilable to the candidates for adoption (exclusive of those adoptions by relatives) to determine their eligibility for adoption. Excluding children who are poor adoptive risks, there is an important aspect of adoption to be taken into consideration, namely, that of the matching of the child to an adoptive home in which he can adjust satisfactorliy. The test of

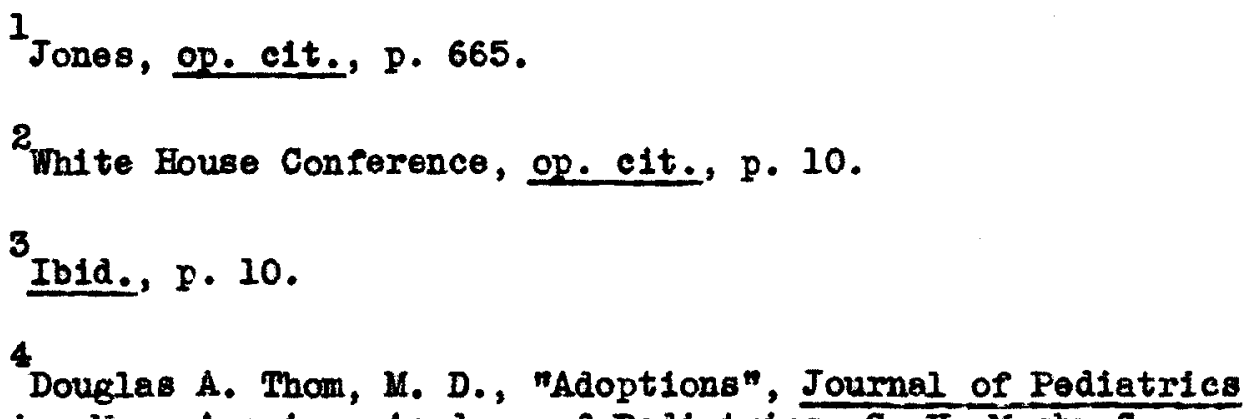

(St. Louis, Mo.: American Academy of Pediatrics, C. V. Mosby Co., Vol. IV, No. 2, Aug. 1939), p. 259. 
the validity of good adoptive plecement is found in its comparison to what might have been the natural home of the child, had there been no need to make an adoptive plan. W1th the social study of the hered1tary background, the findings secured in periodic physical examinatlons, a perlod in a temporary foster boarding home for exploratory study of the child's developmental progress and behavioural status, and a series of periodic psychological examinations, a falrly adequate oraluation of the potentialities of the candidate for adoption can be 1 made.

Following the completion of this comprehensive atudy, which is the procedure of a caseworking ageney, a matching adoptire home can be selected with a reasonable amount of assurance that the over-placement or the under-placement of the child will be aroided.

ADVANTACES OF THE NEY ADOPTION IAN

Probably because the first conception of adoption was allied with Inheritance and support, the legal procedure of adoption was placed under the jurisdiction of the court having to do with property rights. Under Kentucky's old adoption law of 1892, adoption was under the clreuit court. The new law of June, 1940, placed adoption under the county court, whlch is $108 \mathrm{~s}$ technical and complicated in procedure than 18 the elrcuit court which has jurisdiction over property, one of the most complicated and technical divisions of the law.

1

Norme Philbrick, "The Problem in Knowing Adoption Babies", Paper given at the Child Velfare League Round Table, National Conference of Social Work, Buffalo, N. Y., June 1939. 
Residence

The now law prorides that the adoption take place in the 1 county of residence of the adoptive parents. The old law provided in addition thet the adoption might take place in the county of the 2 institution from which the child was taken.

The States of Arizona, Georgia, and Indiana provide that ju3 risdiction follow the residence of the child. This gives a nonresident the privilege of adopting a child where the child lives.

Kentucky's provision of residence is like that of Calffornia, Delaware, Floride, Idaho, Michigan, Minnesote, Montana, Nebreska, Nevada, North Dakota, Oklahoma, Rhode Island, Utah, Virginla, West Virginia and Wisconain. We think this provision is preferable, because it provides a better opportunity for velid investigation of the petitioners, and offers added assurance to the locel county judge in making the adoption decision. There is additional protection to the child placed by an institution. In the past, there have been innumerablo instances in which adoptive parents have gone to another city, where they are unknown, and adopted a child from an institution. In a measure, this precludes the possibility of valid investigation. There are those who will object to the ruling of locel residence, because they prefer that the records of the child be at a distance from their

${ }^{1}$ See Appendix I for Copy of Adoption Law, Sec. 331 b.

2Carroll's Kentucky Statutes, 1936 ed., Sec. 2072.

3 Knox, op. c1t., p. 101.

4

Ibia., p. 107. 
residence, feeling that the records are less likely to be accessible to those of their acquaintance. However, the new law provides that 1 records are to be confidential and are to be seen only by court order, which would remove this difficulty.

\section{Parties to the Adoption}

There are three parties, or sets of parties, concerned in the adoption proceeding. The child to be adopted, with its natural living parents, if born in wedlock, but if not, then its mother, if living, and any testamentary or etatutory guardian it may have, shall be made parties defendant to the petition for adoption. If the child's parents are dead, and there is no guardian, the person or persons stand2 ing in loco parentis shall be made parties defendent. If the care, custody and control of the child has been lawfully transferred to any charitable institution or association, the institution or association is deemed as standing in 1000 parentis and shall be a party defendant to the adoption petition.

If the care, custody and control of a child has been transferred, the consent of the natural parents or of the mother is not legally required. However, we want to stress the importance of giving parents every opportunity to participate in the decision for an adoption plan, since the procedure severs the child's relationship to his

${ }^{1}$ See Appendix I for Copy of Adoption Law, Sec. 331b-10.

2 in 1000 parentis - in the place of parent.

3 See Appendix I for Copy of Adoption Law, Sec. 331b-3. 
natural parent or parents. We were interested in observing that the county home for dependent children (which are committed to it by the juvenile court) in all adoptions, makes every effort to locate the parents for a signed consont to adoption, as part of a casework pro1

cedure. A local private agency has the natural parents or parent enter appearance in court and request the judge to transfer the legel custody of the child to the ageney, before an adoption plan 18 made. This offers protection to the ummarried mother who is saved the ombarrasament of appoaring at the adoption hearing. It also gives the adoptire parents protection by aroiding the possibility of the identity of the adoptive parents beconing kown to the natural parents or parent. Kontucky, like Alabama, California, Delaware, Kinnesote, Horth Dakota, and Hisconsin, places the authority for consent to adoption in the state department, while in New Jersey and Ohio the state department or an agency serving as next friend can give consent to the 3 adoption.

Kentuck's new law merely states that any adult resident may petition to adopt a child or another adult, with the provision that both husband and wife must be parties to the petition. The States of Cal ifornia, Montana, Novada, Now Jersey, Now Moxico, North Dakota, Oklahoma, South Dakota, and Utah specify that the person who is adoptIng must be at least ten years older than the one wo is to be adopted,

IVerified by the Louisville and Jefferson County Children's Home, Lyndon, KY.

$$
\begin{aligned}
& \text { ZVerifled by The Children's Agency. } \\
& \text { Knox, OR. Clt., p. } 102 \text {. }
\end{aligned}
$$


wh1le Idaho requires that the person adopting must be fifteen years 1

older then the person adopted.

Kentucky requires that a guardian ad litem be appointed for

a minor parent giving consent to adoption, and that the guardian

23

ad litem concur with the giving of the consent to adoption.

It 18 the prectice of some locel institutions engeged in chlld-placing, to secure only a notarized consent for adoption from the mother. Iater, when an adoption petition is filed and it is necessery to 1ssue a warning order for the appearance of the mother at the adoption hearing, hor current adress is often unknown and it is 4 imposible to locate her. It would seem that, in addition to the signed consent, it would be advisable to have the mother enter appearance in court, requesting an adoption plan with the legal custody of the child transferred to the institution making the permanent plan for the child. This would remove the chance of future interference on the part of the mother, since there had been absolute removal of her rights as a parent, and would contribute much to the security of both the adoptive parents and the child.

The new law repealed the provision relative to institutions advertising once a week, for a month, in the newspeper of the county

1

Ib1d.

2

ad litem - "for the outt" as defined in Cochran's Law Lexicon - 3rd Edition, p. 10.

3 Soe Append1x for Adoption Law, Sec. 331b-6.

4 Verifled with Our Lady's Home for Infants, and All-Prayer Foundlings Home.

5 Carroll's Kentucky Statutes, Sec. 3310-9. 
of the chlld's residence from which it was comitted, giving printed notification that an adoption plan was about to be made. If the parents or relatives objected, the hearing was to be handled as an equi1

table action. This is not necessary if the institution has casework service and a supervisory contact has been maintained with the natural parents or relatives. The plan of adoption is considered only if it is elrst ascertained that no placement can be brought about with the fanily or relatives.

A definito concept in child wolfare is contained in Part III of the Children's Charter: Tror every child a home and that love and security which a home provides, and for that child who must receive foster care, the nearest substitute for his own home." The new adoption lar provides that the child, if he has reached the age of fourtoen must attend the adoption hearing and give his consent in writing 4

in presence of the court. The court may waire the eppearance of a younger child.

\section{Social Investigation}

The new law specifically states that a social investigation must be made of the former environment and antecedents of the child, for the purpose of ascertaining whether be is a proper subject for

${ }^{1}$ Carroll's Kentucky Statutes, 1936 od., Sec. 2072.

White House Conference, On Dependent Children, Nashington, D. C., 1909, from the report of 1933, op. cit.

3 Soe Append1x I for Copy of Adoption Law, Sec. 331b-4.

4

See Append1x I for Copy of Adoption Law, Sec. 331b-5. 
adoption, and of the petitioner to determine whether the home is suitable for the child. The report is to contain a full statemont of facts found and reconmendation as to the desirability of the 1 adoption.

Following the filing of the petition, the court notifies the Department of Welfare, Child Welfare Division, Frankfort, Kontucky, of the date of hearing, to be held not less than sixty days later, and orders the appearance of the representative of that agency at the hearing.

It is during the sixty-day period that a caseworker from the Child Welfare virision Visits the adoptive home, not just once, but often enough to know the adoptive parents and the candidate for adopt1on. The Child Welfare Division may delegate a child-placing agency In the community to make the investigation, or as scmetimes is the case, the ceseworking agency which has made the placement may be delegated to make the investigation and appear at the hearing. In the serenty-five adoptions used in this otudy, the Ohild Welfare Division representative made fifty-nine social investigations, the Louisville and Jefferson County Children's Home made six, the Home of the Innocents, one, and The Children's Agency did the investigation for nine of the adoptions.

An extension of time may be requested, if necessary, and this 1s often the case when parts of Investications have to be made in remote sections of the state. Out-of-state correspondence is some-

${ }^{1}$ See Appendix I for Copy of Adoption Law, Sec. 33Ib-4. 
times necessery. For this reason, would recamend thet the period 1

for Inrestigation be extended. The County Judge, when interviewed, stated that he was content if the confidential report of the investigation reached him the day of the court hearing.

The making of social investigation cerries tremendous responsibility for the caseworker. It is she who has collected the data, weighed and submitted them to the Director of the Child Welfare Difision who, after objectively eraluating them, gives the consent of the department to the adoption. We like to think of the Child Welfare Dirision looking for the answers to a child's questions as put by tho ominent psychlatrist, Dr. Douglas Thom. The questlons are: Who is to appear in the interest of the child and inquire for him? Why do these people want me? What kind of people are they? Are they thinking of someone to support them in their old age? Or do they want something to play with for the moment? What have they done to demonstrate that they are capable of bringing up a child? Has it ever occurred to them that I might not have chosen them had I had any say in the matter? How old are these respective parents of mine? Iet them consider how old they will be when I am in need of counsel and advice in early adolescence."

The social investigation prior to the final step in the adoption procedure is a constructive measure, but it should begin before the child is placed in the adoptive home. It is evident thet the

Tark Beauchamp, County Judge, August 23, 1942. 2Douglas A. Thom, Normal Youth and Its Froryday Problems, Now York: 1932 , pp. 35-37. 
removal of the child from the adoptive homo is eraught with insurmountable threats to the security of that child, because therein are perhaps the only family ties he has erer known. Often, the adjustment cannot be on a highly satisfaetory level becauge of the child's inadequate abilities to meet the expectations of the adoptive parents or what is termed "overplacement" or the parents cannot meet the desires of the superior child and an "underplacement" results. Iore and affection are major factors in buflding up the security of the child but clashes of contrasting abilitios set up barriers to the development of a thoroughly satisfactory perent-child relationship. Therefore in the final analysis, it may be agreed by the social worker making the inquiry and presenting the findings to the Child Melfare Dirision (as a basis for evaluating the adoption situation) to approve the adoption as it stands. Such limitations can be avoided if skillod persons in approved adoption practices have ontered the situation earlier or more specifically at the time an adoption plan is being considered. The physician, the poychologist and the technically trained social worker, as part of the agency casework procedure, can ascertain the candidate's level of adoptability and prepare a placemont plan in a home which is commensurate with the child's potentialities, as indicated through these scientific or technical services in current use by caserorking social agencies.

Factlities for psychological examinations may be procured through the Mental Hrgiene Clinic, 610 South Floyd Streat, Loulsville, Kentuck, or through the Child Welfare Division Staff Psychologist, State Department of Welfare, Frankfort, Kentucky. The Loulorille and 
Jeffers on County Children's Home has its own Staff Psychologist. The foster boarding home used for study and exploration of the candidate for adoption durine the period of preperation for adoptive placement in a permenent home is a vital part of the casework service given durIng the periodic testing by the psychologist.

Trial or Probation Period

The trial period, or period of edjustment, varies in the different states from $8 i x$ months to one year. The states which provide for a trial period are: Alabama, Arizona, Arkansas, Delaware, Diatrict of Columbia, Georgia, Iowa, Kansas, Loulsiena, Massachusetts, Minnesota, Now Jersey, New Mexico, New York, North Carolina, North Dakota, Ohio, Rhode Island, South Dakote, Texas, Virginia, and Wisconsin. 2 Kentucky's new law requires only three monthe. We should like to recomend that this period be extended to at least aix months. Many child-placing agencles require a probation period of a year.

In reply to an inquiry made to the Child Welfare League of America in respect to the origin of the probation period of a year, we were told that it was not known where the practice originated. It was pert of the developing movement toward the requirement of a probation period. The period of one year was arrived at because that seemed to be the time which served to make clear to a large number of prospective adoptive parents that they did or did not want the child in

1 Knox, o․ cit., p. 12 .

2 See Appendix I for Copy of Adoption Law, Sec. 33Ib-3. (When the bill was presented to the Legislature, a period of one year pas requested). 
question. The purpose of the year's period of probation before actual adoption was to give the prospective adoptive parents an opportunity to see how it feels to have a child, to see whether they really want the particular child, and to observe and help the child to adjust to his new parents. Most frequently the psychological and physical examinations have been attended to before the placement in the adoptire home, during the period of placement in a temporery study home. Placement with adoptive parents is an indication that to all intents and purposes the child can be adopted at the end of the year if the paronts and the child can make a go of 1t. These are not standards confined to members of the Child Welfare League of America, although they are more largely observed by League members than by others.

The probation period should be long enough to allow no element of haste to enter into it. In some of the adoptions studied the probetion period was a very short one, covering only the three months period required by law. It is recomended that the probation period be extended to at least year. This objectire regulation would mean that no adopt1ve parents might feel that they had been discriminated against as they would if requested to extend the probation period. This falls in line with the experience of egencles reporting to the Child Welfare League of America tho are in agreament to a falrly high degree that the probation perlod should be of at least a year's 2 length.

1

IVerified by written correspondence with urs. Henrietta L. Gordon, Information and Publications Secretary, Child Melfare League of America, dated Aug. 18, 1942. 
The probation period, when required as part of the adoption procedure, will be accepted more easily during the period of supervision by child-placing agency. It is our opinion that the probation period without adequate supervision is almost meaningless. It is here the experienced caseworker, with specialized techniques, is noeded. Her technical ceserrork knowledge helps her to be keenly aware of att1tudes in the situation, which are difficult for the adoptire parents to verbalize or, at some polnts, even to recognize. Howerer, it is not easy, once the child hes been placed in the adoptive home, to remove him. Removal depends upon the degree to which the child's security is threatened, particularly in situations where the child has been in the home over a long period of time. If the prospective adoptive parents are to feel no frustration, overy resource of the caseworker is called into operation to persuade those individuals that perhaps a more suitable chlld can be found for them, better able to accept the advantages of their home and affections. Obviously, the greatest amount of care should be used, esrlier, in selecting the right child for the adoptive home. If the placement is made with special preparation, there should be no need to break up an adoptive placement.

\section{Logel Status of Adopted Child}

The new law provides that the adopted child, for all purposes of Inheritance and succession and for all other legal consequences and incidents of the natural relation of parents and children, shall be to all intents and purposes as a child born in lawful wedlock to the 
adoptive parents.m If the adoptive parents do not survive the adopted child, the property of the decessed adopted child, without issue, shall go to the natural parents in the line of descent and distribution; but in the event that the natural parenta are dead, his property ahall descend to the natural and adopted relatives under the same provisions as are now or hereafter provided by Section 1393 of Carroll's Kentucky Statutes, 1936 edition. I Kentucky, like the States of Alabame, Arkansas, Colorado, Florida, Malne, Massachusetts, New Jersey, Hew York, Ohio, Texas, and West Virginia, provides that an adopted child does not 1080 the right to inherit also from his natural 2 parents.

It is here that criticlsm is often given. The adopting paronts, uaually, profer that the natural parents do not know the identity of the adoptive parents and thoir whereabouts. The social worker feels that the natural mother has a right to proceed through life without the hazard of the existence of her child becconing known. Lawyers tell us that the blood-1ines of inheritance must not be broken. We wonder if an adopted child should inherit from two sets of parents, and is this provision of inheritence, often a remote possibility, a bar to the child's future emotional security? Natural parents who have carried their responsibilities so lightly as to lose custody of their child, and unmarried mothers, some of whom are notebly unstable in their behaviour, may create serious problems for the adoptive child, if they

${ }^{1}$ See Appendix I for Copy of Adoption Law, Sec. 331b-8.

2 Znox, op. eit., p. 107. 
can, at will, re-onter his life at a later date, possibly for material gain. What emberrassment will the child suffer? It is a controversial subject and one in which adoptive legislation will be changed only with enlightened opinion, as more and more, the social aspects of adoption come to be better understood and accepted. It is our opinion that if one belleves in the greatest good for the greatest number, there $\mathbf{w 1 l}$ cone a conviction that a complete severance of the natural parent relationsh1p is more favorable for the chlld adopted by persons other than relatives.

By the adopt1on procedure in Kontucky, the child is freed from all legal obligations of maintenance and obedience to the natural 1 parents. The logal rights of the natural parents have been transferred to the adoptive parents. Adult children in Kentucky are to support their "poor" parents. The penalty for fallure is one to $\$ 1 x$ months in jall or workhouse.

\section{Birth Certificate}

The adopted child's name may bo changed in the court order to that of the adoptive parents. The old law left the change of name to the discretion of the judge, and there was no provision for a re-certification of birth.

After the entry of the court order, the clerk of the county court is required to report promptly to the State Board of Health,

1

${ }^{1}$ See Appendix I for Copy of Adoption Iaw, Sec. 331b-8.

2 Carroll's Kentucky Statutes, Soc. 331-1.

3 Carroll's Kentucky Statutes, Sec. 2072-a. 
Bureau of Vital Statisties, the necessary infomation to issue a new 1

birth certifleate in the new name. The now birth certificate is filed with the original birth certificate.

The County Clerk is rosponsible for delivering to the Bureau of Vitel Statistics the necessary information to prepare the new certificate. This information includes the prior name of the child, the date and place of birth of the child, the name or names of the natural paronts, the neme, address and occupation of the adoptive parents, the new name of the child, the date of the adoption order, and the change of namo.

The new law provides that no person having charge of the birth record shell disclose the name of the adoptive parents without a court order Irom the county court in which the adoption took place.

About one-third of the states have authorized the State Burean of Vital Statistics to Issue all birtb certificates for an adopted 3 child under his legal neme. Therefore, when proof of age is necessery for school entrance, for work certificates, for social security requirements or for other purposes, the certificate 1ssued bearing the surneme of the adoptive parents w11l prevent any question of the situation surrounding birth. Kentucky specifically limits the issuance

1

See Appendix I for Copy of Adoption Iaw, Sec. 331b-7.

2 See Appendix I for Copy of Adoption Law, Sec. 331b-10.

3

Agnes K. Hanna, "Spocial Certificates for Adopted Children", The Child (Tashington, D. C.: J. S. Children's Bureau, May 1942), p. 289.

4. S. Children's Bureeu, Folder 13, "Adoption", Washington, D. C., 1938, pp. 13-14. 
of new birth certificates to children born in the state.

The new birth certificate bearing the names of adoptive parents is in no sense to taks the place of telling a child ho is adopted. There is always the possibllity that the child might learn it from unfriendly sources. Certeinly, when the child grows older and wonders who his own parents were, why they gave him up, and where they are now, the adoptive parents should answer these questions honestly and in a manner adapted to the child's understanding and emotional needs. Dr. Knight has suggested that sometime during the fourth year is good time to begin interpreting the adoption to the child. In discussing the adoption, the adoptive parents are to make It sound desirable and pleasant to the child. There is some security in thinking that the child's parents had positive qualitios as well as negative ones and that there must have been real reasons why they found it necessary to entrust him to someone else.

In our opinion, the chlld-placing agency should be extrenely careful to see that the new bixth certiflcate is issued for each adopted child placed through the agency. The obtaining of a new birth certificate should be considered as a part of the service to be supplied by the agency, which is basically resonsible for the adoptive placement.

In July, 1942, it was verifled with the Bureau of Vital Statistios that in fifty-five of the seventy-five adoptions included in this study, a new birth certificate had been issued.

1 Hanna, op. e1t.

2 Robert P. Knlght, M. D., "Some Problems Involved in Selecting and Rearing Adopted Childron", Bulletin of Menninger Clinic, Vol. 5, No. 3, Topeka, Kanses, May 1941, p. 65. 
Certain provlsions in the statutes relating to the Bureau of Vitel Statistics have particular significance to the phrsician. He is charged with the responsibility for reporting births, within ten days, and if ho neglects to flle a "proper" birth certificate, shall be deomed guilty of a misdemeanor. If convicted, he will be fined not 1 less than five dollars nor more than fifty dollars. Any person who wlfully alters a birth certificate sholl be deemed guilty of a misdemeanor. If convicted, there shall be a fine not less than ten dollars nor more than one hundred (100) dollars, or imprisonment in the county jail not exceeding sixty days, or at the discretion of the court, both the fine and imprisomment can be imposed. We assume that these provisions would act as deterrents to othieal physicians In attendance on unwod mothers who try to conceal the child's real identity.

The Role of the Physician in Adoption

With respoct to doctors placing children for adoption, we were interested in an editorial appearing in a medical journal describing 3 one of Oregon's statutes prohibiting the placement of children for adoption by other than relatives and licensed child-placing agencies. It was statad that in warning doctors, nurses, midwives and hospital officials especially against such particlpation, the statute is

\footnotetext{
${ }^{1}$ Carroll's Kentucig Statutes - Sec. $2062 a-22$.

2 Ibid.

${ }^{3}$ Oregon Code, Sec. 31-716.
} 
protecting individuals under the greatest pressure from those seeking children to adopt, for many are such persistent seokers, and they can and of ten do make nulsances of themselves, especially to busy doctors. The statute also tends to protect the medical practitioner from any appearance of participation in the shady profession of baby-farming, which, in roality, is traffic in babios.

The modical profession is urged by the Child Welfare Comnission of Oregon to make full use of the licensed child-placing agencles by referring to them, children noeding foster homes and adults soeking foster children. This practice frees the doctor from responBibility for a major social operation, the severing of a child from his own family and grafting him into a strange setting, a procedure which may or may not have a successful outcame. It relleves him of the time-consuming tesk of assembling and verlfying detatled information, ossential to high quality work in this 1ino, a process requiring a technique wholly outside the medical profession. Wherever the services of an agency can be utilized, and it is equipped to approach the problems of adoption from all its raried angles, medical, social, psychological, and legal; the physician would do well to allow those proIessionally trained people do the job, the doctor acting in the capacity of family adviser and cooperating with the ageney and the fanily 2 to bring about a satisfactory result.

In order to protect all persons inrolved in placing a child for adoption, we should like to recomend that the legel statutes of

1

Editorial, "Doctors and Infant Adoptions", Northwest Medicine (PortIand, Ore.: Oregon, Washington and Idaho State Modical Associations, Vol. XXXII, No. 11, Nov. 1933), pp. 479-480. 
Kentucky provide for making it mandatory that all situations relatire to the relinquishing of a child for adoption be referred to the child Welfare Dirision for social investigation and assistance in making the plan.

Placements of children by persons or agencies not properly licensed for such service was prohibited by the laws of six states of the nine included in an adoption study in 1941 by Miss Mary Ruth Colby of the United States Children's Bureau.

\section{Annulment of Adoption}

The old Kentucky law had an interesting provision for annulmont. If an adopted child became so disobodient to his or her foster parents that the peace and happiness of their home was thereby destroyed, the adoption could be annulled any time after the child bad passed his or her seventeonth birthday. There was an accompanying provision that the foster parents, court, and institution entering into the adoption must be in mutual agreement. This section was repealed with the enactment of the new adoption law.

Since the adopted child assums the role of a natural child, provisions for annulment seem unnecessary, except in cases where it is to the advantage of the child. A parent is not thought of as being able to repudiate his natural child. We do conerr with Minnesota's

\section{1}

Colby, Problems and Procedures in Adoption, op. eit., p. 42. These tates are Alabema (1923), California (1937), uinnesota (1927), Phode Island (1938), Oregon (1930), and Wisconsin (1939).

2

${ }^{2}$ Carroll's Kentucicy Statutes, Sec. 2072b (1934, e121, Sec. 1, Effective June 14, 1934). 
provision: that if within five yeare the child has dereloped cortaln defects - such as feeblemindedness, insenity, epilepsy or renoreal disease - from conditions oxisting prior to the adoption and then unknown to the adoptire parents, the decree may be annulled. The probability of the occurrence of these situations can be eradicated In the majorty of instances by comprehensive social studies of background, and the use of physical, psychlatric and psychological examInations prior to placement of the child in the adoptive home.

\section{Rstablisbment of Paternity}

The legal establisment of paternity is of interest in relation to adoption because, first, it offers a means of securing maintenance for the child until he or she is sixteen, thereby helping an unmarried mother keep her chlld if sho so desires, and, second, it insures the inheritance rights of the child through patermal blood11nes. If paternity is established, it removes the possible stigma of promiscuity of the mother. Of importance, if an adoption plan is considered, the establishment of paternity enables the ageney to give the background of the child to the adoptive parents with some degree of ralidity.

In bastardy cases the procesdings are civil and not criminal, and the chief object 18 the berefit of mother and child. The mother is not 11able for costs.

1 Knox, op. cit., p. 108.

${ }^{2}$ Carroll's Kentucky Statutes, 1930, Sec. 167, 181 and 978.

3 3

Chandler v. Com., \& Met. 66 ; Francis v. Com., 3 Bush. 4. 
1

Any umarried mother within three years after the birth of the child can make a bastardy flling. A warrant is served on the alleged father and he is required to give bond for his appearance. The county court of the county in which the child is born or in which the mother resides, if the child was born out of the state, has jurisdiction. The defendant may request a trial by jury. If the finding of the jury is against the defendant, the couxt shall order an annual sum (commensurate with the rather's earnings) paid periodically until the child is elxteen. Payments by the father are made to the mother through the Jurenilo Court. This is an adrantage because they are recorded and can be given as proof (if the need arises) that the father is carrying out his obligation.

During 1941 there wore flfty-two bastardy filings in Jefferson 2

County. Often the alleged father will voluntarlly ackowledge paternity. This is the preferable procedure and insures more privacy in the matter. The social worker, with the consent of the mother, usually visits the alleged father (the child's father has a right to be consulted) and if his attitude is a cooperative one, voluntary proceedings are encouraged. The County Attorney or his assistant is glad to represent and attend to the matter. It has been our experience that the establishment of paternity does not necessarily moen that the unmarried mother recelves maintenance for the chlld to assist her in keoping it. The father mey, if he is unemployed, go to fall and give

1

A married woman does not have legal recourse.

2

Verified with records in County Clerk's Office. 
the County Attorney ten days notice of intended application for discharge, take pauper's oath and absolve himself fram any further 1

responsibility toward matntaining his child.

In spite of this adrerse espect, it is well to establish patermity since it is impossible to know that the father will have some estate at his death, to which the child will be entitled only if paternity was established.

\section{Agency Procedure}

Agency placements are said to protect the interests of the natural parent, and hence relieve the adoptive parent of the guilt of possible indirect coercion. The agency with a casework program can offer a reasonebly complete knowledge of the chlld's background and potentialities and some shering of responsibility, since it selects for the family's consideration only a child who might be satisfactory for this particular home; and agency procedure prevents hasty and 11l-considered action in choosing a child. Prospective parents aro given as much time as they need to get acquainted with the child and make their decision, and only after a trial period do thoy assume conplete responsibllity through legel action.

There has beon eriticism of the time element involved by agency procedure, and the lay public has expressed impatience with the

1

Carroll's Kentucky Statutes, Sec. 169.

2

2Minnesote was the first state to require a trial period of residence", excerpt fram a letter from Miss Mary Ruth Colby, U. S. Children's Bureau. 
ageney's delay in the adoption procedure. Miss Smith felt a certain part of the community wanted the adoption procedure "streamlined", apperently desiring the agency to take more babies and to make more 1 babies available at an earlier ago. It is hero that some institutions, physiclans, relatives and friends of the child's parent have stepped in to speed up the process in placement, encouraging the placement of infants for adoption. We all know that some so-called haphazardy planned adoptions have turned out successfully, but we believe we have passed that point in this community, now that our attention has been focused by the new adoption law on the social aspects, involving the use of specialized techniques, in adoptive placement. Accepting the agency-procedure as the more skilled method, the law challenges agencies, institutions, doctors, and others to work toward a more comprehensive program of chlld-placement with the use of all of the current and avaliable technical skills for better adoptive placements.

\section{Adoption Statistics}

Prior to the law of 1940 , there was no centralization of adoption stetistics in Kentucky. The adoption cases, along with all others in the circuit court, were unclassified. The only way to have ascertained the number of adoptions in Jefferson County for comparison with the year of the study, 1941, was to have examined all cases which

I Mary Frances Smith, "Adoption as the Community Sees It", Journal of Social Work Process (Philadelphia, Pa.: Pennsylvenia School of Social Work, Vol. III, No. 1, Dec. 1939), p. 13. 
wore on docket for each respective year. The Child Wolfare Division, 1

Frankfort, Kentucky, has an Adoption Register in whlch each adopti on petition is recorded. With the Adoption Register centrelizing the Information, comparisons of future years will be oxpedited. It is even now possible to secure the adoption rates of only a few states, because sdoption date are not well dereloped.

The aspects of adoption which have been described thus far will assist in understanding the chapters on The Natural Parents, The Candidate for Adoption, and The Adoptire Parents, in their relation to the seventy-five adoptions included in this atudy. Bearing in mind the trend in American adoption procedure and the provisions of the new adoption law in Kontucky, we will be able to make an analysis of the material examined in the following chapters.

Before proceeding to the next chepter, we will describe briefly the four cases of 1941 not included in the study, which were as follows:

1. One adoption was postponed indefinttely by the court, following the Child Welfare Division's recommendation for deferment. The adoptive mother, a relative of the child (14) had active tuberculosis, which would threaten the future security of that child. In the process of investigation, health information had been rerified with

1

Established June 1940.

2 Verified by correspondence with Miss Mary Ruth Colby, Sociel Service Division of the U. S. Children's Bureau, and Mr. Ralph Furlin, Director of Statistics, Russell Sage Foundati on. 
the Board of Tuberculosis Hospitsl Clinic.

2. and 3. Two children, under five and not related, for whom the same adoptive parents had filed petitions, were removed fran the city, following a series of court hearing postponements, as rocommended by the Child Welfare Divial on, for further investigation and supervision. The adoptive mother was fifteen years older then the adoptive father, and she was a permanent cripple. References stated that the adoptive mother had an unruly temper and gave evidence of being unable to manage, with any degree of adequacy, her finances. The adoptive father had superior earning ability. He was transferred by his employer to another state.

The Child Welfare Division, through 1ts Director, offered casework service to the institution which hed placed the children, with the alternative of having the children comitted to the public agency. The children could have been placed with younger adoptive parents who could have participated more satisfactorily in future family relationships with these children. The point which interested us was that these children went on to another state apparently with no plan for agency supervision.

4. The adoption petition of an adult son by the mother and stepfather was refused, because they were unnaturalized residents, and the court ruled: Wot entitled to refuge in our laws". 
CHAPTIFR II

THE NATURAL PARENTS 


\section{CEAPTIR II}

THE NATURAL FARENTS

In this chapter we will endeavor to assemble and classify the findings to show that which indicated what kind of individuals the natural parents of the cases in our study were, what happened to make it necessary for them to relinquish their child, how the parents maintained thomselves, their age, their maritel status, their ability to use resources furnished by their own efforts or in the laws and provisions of the community for the support of these children. Accepting parenthood as a partnership relationship, wo have observed the physical condition and mental ondowment of these parents for ovidence of the cause of breakdown in their parentel roles. It is with this knowledge, we can weigh the hereditary factors with some degree of validity when matching a candidate for adoption to prospective adoptive parents.

The court reports contalned the information about the parents, where it was possible to obtain that information. The lnowledge of the natural background of a child is what distinguishes professional from cesual placoments of children for adoption. Because in fifteen of the adoption situations, placements were made independently of an agency, and a large number of others were made by institutions not having, at the time of placement, a casework service, much of the background material was not collected or recorded. We can underatend in the fourteen adoptions in which the natural mother and the step- 
father were the petitioners for adoption, that some of the background information would not necessarlis be included in the court report, because there would be no need for an exhaustive study.

A sketchy picture of the natural parents is gained fram the court reports, but we could expect little else; when wo consider that almost one-third of the children who were being adopted had been in the adoptive hame ercon two to ten years or over. Considering the periods of time which had elapsed, it would bo highly difficult to secure a fairly complete beckground history for the social investigation of the child, unless the adoption plan had been made by an agency which kept full records on those children under its supervision. Howerer, enough information is contained in the roports to indicate a pieture of some of the factors in the background which brought about the need for adoption plans for the children in this study. We agree with Dr. Thom, that jeopardizing hereditary background is one of the factors to be considered in declding whether or not the child is a 1 good adoptive risk. Only an adequate evaluation of the hereditary background can give same assurance of the absence of unfarorable inIluences on the future of the child.

\section{Birthplace, Nationality and}

Formal Iducation of Natural Parents

The location of the birthplace for each of the twenty-seren nothers whose children were born in wedlock was as follows: Seven in Iouisville, oight in other counties of the state, three in other

1 Thom, Adopt Ions, op. e1t. 
states, and nine not reported. For those motbers whose children were born out of wedlock, eighteen were born in Louisville, sixteen in other counties of the state, and the birtbplace of fourteen was unknown.

For nationality, in most cases, American was given. InterestIngly enough, for the unmerried mother there was some report of foreign extraction with three described as German, two Irish, end two of English descent. On only one was the alleged father's forelgn extraction noted, and that, as an Italian. If we think in terms of a child's appearing as one who belongs, it is beyond question that certain inherited physical characteristics should be noted in the matchIng the child and the adoptive parents.

The degree of formal education attained can hardly be considered indicative of whether the individual can or cannot be selfmaintaining, because it is highly possible that an oconomic need to seek work and the degree of emotional stability nay color the situation. However, the amount of formal education does, in a measure, point toward limitations in rocational achlevement and in cultural levels which might possibly be attained.

In considering the natural parents' education, we first viewed the father's educational preparation. In the twenty-seven situations involving the children who were later adopted, seven had completed the eighth grade, one had some high school education, one completed high school, one completed college, and one was said to be "llliterate, having come from the backhills of Kentucky". For sixteen there was no report of educational background. 
For those mothers whose child was born in wedlock, a similarly incomplete report was given. Ten completed the sixth grade, one the serenth, and six the elghth, while one was described as liliterate, as was the father in this situation. Three had some high school training, one was said to have been graduated. One mother of the nine who, with the stepfather was adopting her own child, had graduated from an Eastern college. For eleven no information was given.

The educational attainment of twenty-three individuals, countIng mother and a father in each situation, presumably was unknown, since the educational level was not given in the reports. This information would have helped to predict the possible educational attainment level for the children of those indifiduals.

No psychological findinge were given for the married natural parents.

In exploring the educational background of the forty-eight unmarried mothers, we found that thirteen had completed from ifve to nine grades of school; five had attained the third year of high school (two of those had been forced to discontinue school at that time because of pregnancy); sixteen had completed high school; and three had some work on a college lovel. Seven umerried mothers had special training; three in business college; two were graduates of nursing schoola; one had some nurse's training; and one, a colored girl, had attended a vocational high school for negroes, in mother state. The court reports gave information for forty-four, leaving only four whose school background was unknown. 
Iegal paternity was established on only two of the children, 1 whlch explained the absence from the court reports of information relative to the educationel achievement of all except two of the al leged fathers, one a graduate of bigh school, and the other having had three years of high school.

On the whole, from the court reports, the educational level is b1gher for the umarried mothers than for the wedded mothers whose children were placed for adoption.

\section{Psychological Findings}

The practice of psychology has been defined as "the application of the principles and techniques of psychology to the measurement, eveluation, explanation, interpretation, motivation, guidance or redirection of human behaviour". Psychological measurement may be considered reasonably reliable in evaluating an individual's ability to achiere.

The court reports gave the findings of psychological exeminations for twelve of the unmarried mothers. The Child Welfare Division Staff Psychologist had exemined two mothers, one with a rating of "High Grade Moron", and the other of "averege" intelligence. The Mental Hygiene Clinic Paychologist had examined seven of the unmarried

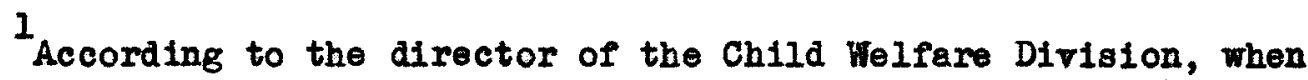
legel paternity has not been established, it is the policy to omit all information concerning the alleged father. Child-Placing Agency", The Femily (New York, June 1941), p. 122. 
mothers. The intelligence ratings were, respectively: three of "average"; one of "high average"; two of "low average"; and one of "borderline" (Submissive Type). The Louisville and Jefferson County Chlldren's Home Staff Psychologist had tested one mother while she was a ward in that institution, and the rating was given as Feebleminded Imbecile". (Of interest in the subsequent evaluation of the child's intelligence, the alleged father, also a former ward, had been examined and rated of "average" intelligence, which would somewhat offset the mother's low rating in her test when predicting the heredity of their child.) One mother had been examined at the request of the Jurenile Court in another state, where she became involved in an episode with a charge of delinquency. At that time, the rating given her was "borderline" Intelligence. We do not question the value of these tests in working out plans for these respective mothers.

\section{Occupations of Natural Parents}

In what occupations did these mothers find placements? The court reports gave information on only seven of the married mothers, possibly because the majority of them were housewives at the time of the child's birth. However, the occupation, if any, of an individual prior to marriage can be meaningful in the evaluation of the stability or the amount of insight into future planning possessed by that person. Two mothers had worked in a factory; one in a meat packing house; two were secretarial workers; and one had intermittent work as a tutor. The occupations of painter and mechanic were listed for two natural fathers. 
The occupational picture for the umwed mothers included: one W. P. A.; four domest1c servants; five waitresses; one owner and operator of a mall store; one stenographer; two students, one of whom had worked in the afternoons caring for children at twenty-five cents per hour; two greduate nurses; one practical nurse; one factory worker; and a statement that ten hed not worked outside the home. Two of the ten were said to have worked "on the farm where they lived". The above picture is bleak when we think of the difficult situation in which the unwed mother finds herself when she tries to support her child and herself. "The experience of social workers assoclated with children's agencles is that unmarried mothers, with rare exceptions, are incapable of providing sustained care and security for their illegitimate babies. When the unmarried mother is bound to her child by an infantile need of love or ties of guilt and aggression rather than by tendermess, affection and generous love; the economic and emotional strain of bringing up a child whose existence jeopardizes her standing in the community far outweighs any possibility of satisfaction from the child. She loses interest or becomes frankly host1le. The child is neglected and rejected and often erentually forced to suffer placement and replacements."

\section{Age}

The age of the mother more often appeared in the court report than thet of the father, possibly because the father, the breadwinner,

${ }^{1}$ Dr. Florence Clothier, "Problems in the Placement of Illegitimate Children", Child Welfare League Bulletin (New York: Child Welfare League of America, Vol. XX, No. 3), p. 2. 
had dropped out of the picture where there was need for an adoption plan.

Twelve, or nearly one-half of the twenty-seven wedded mothers were over twenty years of age. Seven of the wedded mothers, or onefourth, were under twenty years of age. In the group of unwed mothers, seventeen, about one-third, were under twenty. The oldest wedded mother was thirty-five, and the youngest was fourteen. Tho oldest umed mother wes forty-seven, and the youngest was sixteen. of the total mothers, wed or unwed, the largest group, twenty-three, fell between the ages of sixteen to nineteon. This last-named group is made up of individuals who ordinarily would be beginning to think in terms of self-maintenance. It would seem that these mothers had not reached a suitable age to assume the responsibilities of parenthood.

\section{TABLE 1}

AGE OF MOTHER BY MARITAL STATUS

AT TIME OF CHILD'S BIRTE

\begin{tabular}{|c|c|c|c|}
\hline \multirow[b]{2}{*}{ Age of Mother } & \multirow[b]{2}{*}{ Total } & \multicolumn{2}{|c|}{ Marital Status } \\
\hline & & Hedlock & $\begin{array}{l}\text { Out of } \\
\text { Wedlock }\end{array}$ \\
\hline Total & 75 & 27 & 48 \\
\hline 35 or over & 3 & 1 & 2 \\
\hline 25 to 34 & 12 & 3 & 9 \\
\hline 20 to 24 & 19 & 8 & 11 \\
\hline 16 to 19 & 23 & 6 & 17 \\
\hline Under 15 & 1 & 1 & 0 \\
\hline Not Reported & 17 & 8 & 9 \\
\hline
\end{tabular}


Other Children

It was to be expocted that more wedded mothers than unwed mothers would have other children. Of the former, two had four older children, four had two older children lone of these had a younger child, tool, and four had one older child than the adopted child. One mother had one jounger child who was adopted by a couple in another state. In the latter group, the unwed mothers, three each had one older child; one had two, one older and one younger; and one had three illegitimate children, two older and one younger than the child whose court report was in this study.

In examining the situations with other children preaent, we wondered what would have dereloped if benefits of Ald to Dependent Children had been available throughout this state. Since the passage of the Soc1al Security Act in 1935, aid for dependent children has become more generally avallable to the umarried mother.

According to the policies of the former Mother's Aid agency (now known as the Aid to Dependent Children agency) operated under tho Jefferson County Welfare Department and in 1941 wholly maintained by Fiscal Court grants, illegitimacy was no bar to receiving aid. However, there had to be some Indication of stability on the part of the mother. Very young mothers and those with a pattern of promiscuity were not accepted for care. Aid was being administered in some situa-

1

In 1941, there was no state-wide plan for Aid to Dependent Children in operation under the Social Security Board.

2 Colby, Problems and Procedures in Adoption, op. cit., p. 10. "The Social security Boerd reported that in the fiscal jear ig38 to $1939,12,634$ ehildren of unmarried mothers in 40 states, the District of Columbia and Hawail, had been accopted for such aid." 
tions where there was a common-law marriage relationship, and the father had been out of the home for year or, if in the home, was permanently disabled for work and unable to provide for his family.

\section{Health}

The health of natural parents was deseribed in the court report, more often, with the statement, Mother's health was understood to be good at the time of this child's birth." In a fow instances we found such descriptive statements for the mother as, "not sturdy in physique", "undernourished", and "mentally 111 at the time of child 's birth". Five were described as dying on or near the date of delivery of the child. In one situation there was posthumous birth of a child whose mother had died of gunshot wounds inflicted by the father in a drunken rage. The natural father had not beon convicted in the subsequent trial for murder of his wife, but the judge in that county had ordered the father to leave the state and never to return. Often the atatement was made that there had been no discovery of hereditary disease in the beckground. In two ingtances it was mentioned that renereal tests were negative. The cause of deaths for two mothors was given as tuberculosis. Three mothers were mentelly ill and were recoiving treatment in institutions for the care of the mental ly 111.

Terified with Department of Intake, Jefferson County Aid to Dependent Children. 
Reasons for Relinquishing Child for Adoption

Frequently, the lack of economic resources was the reason giren for the natural parent resorting to an adoption plan for the child. Often the Confidential Report included more than one reason. In Table 2 we have used the first reason given for the adoption plan, assuming it was the most influential one. Fourteen or 18.4 per cent of the natural parents petitioned with the stepfather to adopt an own child. The largest group with the same reason, the desire to return to previous status in the conmunity, appeared in that of the unwed mothers. A total of twenty-eight or 36.8 per cent of the mothers wanted to return to their origl nal roles in the community. Ten of the unmarried mothers had a second need caused by lack of economic resources. In one situation the maternal grandparents had taken an older illegitimate child into the home, but refused to accept the responsibility of maintaining the second 1 llegitimate child. Six of the mothers had definite behaviour patterns of instabllity, including persistent delinquency, sexual promiscuity and one had rejected the marital state. Two of the unred mothers wished to conceal the birth of the illegitimate child from their other legitimate children. In two situations the alleged father was not told of the pregnancy. These last two mothers felt that the alleged father would not contribute to the child's maintenance and would inform the community of the child's birth. Iegal paternity was established on two of the children, in an effort to secure financial assistance for the mother, but in each situation the father left the state to escape his responsibility. The reasons for relinquishment for adoption are shown in Table 2 . 
TABIS 2

NATURAL PARFRT'S' RRASONS FOR

RRELINQUISEMRENT OF CHILD FOR ADOPTION

BY STATUS OF CHILD AT BIRTH

\begin{tabular}{|c|c|c|c|}
\hline \multirow[b]{2}{*}{ Reason } & \multirow[b]{2}{*}{ Total } & \multicolumn{2}{|c|}{$\begin{array}{c}\text { Status of Child } \\
\text { at Birth }\end{array}$} \\
\hline & & $\begin{array}{l}\text { Born in } \\
\text { Wedlock }\end{array}$ & $\begin{array}{l}\text { Born } \\
\text { out of } \\
\text { Wodlock }\end{array}$ \\
\hline Total & 75 & 27 & 48 \\
\hline Mother Married to Stepfather & 14 & 9 & 5 \\
\hline Lack of Economic Resources & 11 & 4 & 7 \\
\hline Mother Mentally III & 4 & 2 & 2 \\
\hline Desertion of Father & 3 & 3 & 0 \\
\hline Both Parents Deserted & 2 & 2 & 0 \\
\hline Instability of Mother & 6 & 1 & 5 \\
\hline Both Parents Dead & 2 & 2 & 0 \\
\hline $\begin{array}{l}\text { Desire for Prefious Role in } \\
\text { Community }\end{array}$ & 27 & 0 & 27 \\
\hline Mother Dead & 5 & 4 & 1 \\
\hline Not Given & 1 & 0 & 1 \\
\hline
\end{tabular}

We were curlous about the reason most often given in the situations of unwed mothers, that the mother wished to return to her role in the community. The caserrork treatment of the unmarried mother is a large field within 1tself, and one which we are not attempting to discuss in this dissertation. We do state, with confidence, that adoption is a good solution for the baby whose existence is too great a source of conflict in his own family. We are realistic enough to 
know that it is not a perfect solution, that being adopted involves problems, too, but that for most children, falrly successful adoption can be achiered and adoption carries less conflict than life with a family which, uneble to support a child adequately, rejects the responsibility of the parental roles, and in a community where his status is questionable. We know that some mothers have a special sort of relation to their problem or a need of their babies, which necessitates keeping the child, elther openly or secretly. We know that for some mothers and children the relation between them has values which make a good life possible or make, at any rate, a separate existence impossible, but for those mothers who want a more normal social life for their children than keeping them can provide, for those who are mentally 11l, or because of youth and lack of preparation, unable to rear their children, and for those to whom their babies constitute a tangible evidence of guilt, we beliere in adoption. A comprehensive description of the attitudes of unmarried mothers as revealed in agency planning is given by Miss Ruth Brenner.

At this point, we may consider the reason for certain information about adoptive parents being given in the confidential court report, which is filed with the adoption order. It would seem that if such records are necessary, in case an adopted child, in his subsequent

${ }^{1}$ Julia Ann Blshop, "The Child's Part in Adoption Placement", Adoption Practice (Case Work with Parent, Child and Foster Parents), (New York: Child Welfare League of America, Dec. 1941), p. 11.

2Ruth F. Brenner, "Cesework Service for Unmarried Mothers", The Family (New York, Nov. 1941, pp. 211-219, Dec. 1941, pp. 269-276). 
conflict or curiosity about his natural background, should ask for information concerning his adoption, the fact that some eridence in the court report pointing toward his parents' relinqui shment of him, gave reasons with which he could be fairly sympathetic would be of positive value, particularly from the standpoint of mental bygiene. The report should contaln constructive information for that child. For instance, we can conceive of an adolescent boy or girl who is normally possessed with the urge to examine his status in life (who he 1s, and why he is in a certain home) seeking out information about his parentage. If there were no agency to turn to for facts in his background, he would natural iy go to that adoption record for information. We reiterate that, where it is possible, all favorable aspects surrounding the mother's decision to give the child for adoption should be included in the confidentiel court report. In our opinion, this is just one more argument for more agency placements, rather than what Miss Sophie Van Thies cells "casual" placements. The latter type is apparently less concerned with the importance of heredity, and a need for a study of parental backgrounds.

We are in agreement with $\mathrm{Dr}$. Thom, that every parentless child Is entitled to adequate care and to protection approaching as nearly as possible that of a normal home. There 18 a real problem involved in getting the largest number of acceptable children into the largest number of acceptable homes, with the objective of increasing the sum

${ }^{1}$ Sophte Van S. Thies, "Some Aspects of Good Adoptive Practices", Child Welfare League of America Bulletin, Child Welfare League of America, Nov. 1940, p. I 
total of satisfaction derived by the adoptive parents and children with a minimum amount of risk of cxeating incompatible relationships. In skilled adoptive practice it is imperative to know the background of the natural parents. Recognizing that it is extremely difficult to find lines of division between the parts of the adoption process (namely, the natural parents, the child, and the adoptive parents) because they are so closely related, we have presented the material; as far as possible, which would influence the heredity of the candidate for adoption.

Before leaving this part of the adoption process, we wat to point out the ralue of "timing" in the procedure. Timing in good adoptire practice can be skillfully used to give the agency and the indiriduals most intimately connected with the adoption an opportunity for mutual participation and exchange of information. Although the information relative to the natural parents was, at times, fragnentary, we were inclined to feel, when reviewing the marital status of the natural parents at the time of adoption, that had the parents been relnforced by casework service in planning, some of them might have worked out plans with the relatives for the care of the children. A picture of the marital status of the parents at the time of adoption appears in Tables 3 and 4. One questions what part the time el ament had played in these adoption plans. Had the umarried mother been giren ample time to make her decision? Perhaps this feeling

1 Thom, Adoptions, op. eit. 2 Van s. Theis, op. cit. 
comes from having experienced the pressure of the communtty to meet its need for making permenent plans for children of unwed mothers, and the need of the family with the child for adoption. The responsibility of the casework agency is, first, to exhaust all resources to work out with the parents or the mother, a plan to keep the child, if the situation warrants 1t, because we know that the adopted child is never an own child to his adoptive parents. The force of emotional denial of this reality presses from all sides. It comes from within the agency or institution in its desire to give the child the feeling of really belonging to someone; it comes from the adoptive parents in their drive to make the child really their own; and it comes from the child himself in his deep need to have a real father and mother.

\section{TABLE 3}

MARITAL STATUS OF NATURAL PARENTS AT TINE OF ADOPTION BY STATUS OF CHIDD AT BIRTH BORN IN WEDLOCK

\begin{tabular}{l|c}
\hline \multicolumn{1}{c|}{\begin{tabular}{c}
\multicolumn{1}{c|}{\begin{tabular}{c}
\multicolumn{1}{c}{ Marital Status of } \\
Natural Parent s
\end{tabular}} \\
\multicolumn{1}{c|}{ Total }
\end{tabular}} & Number \\
\hline Parents Dirorced & 27 \\
Mother Dead & 11 \\
Father Dead & 8 \\
Both Parents Dead & 1 \\
Parents Living Together & 1 \\
Parents Separated & 1 \\
\hline
\end{tabular}

Ora Pendleton, "Agency Responsibility in Adoption", The Fan1ly, Apr. 1938. 


\section{TABLE 4}

MARITAL STATUS OF NATURAL PARRANTS

AT TTIE OF ADOPTION

BY STATUS OF CHITD AT BIRTH

BORN OUT OF WEDLOCK

\begin{tabular}{l|c}
\hline \multicolumn{1}{c|}{$\begin{array}{c}\text { Maritel Status of } \\
\text { Natural Parents }\end{array}$} & Number \\
\hline Total & 48 \\
\hline Mother Unmarried & 11 \\
Mother Married to Adoptive Father & 5 \\
Mother Widowed or Divorced & 3 \\
Mother Dead & 3 \\
Mother Now Married & 5 \\
Mother and Alleged Father Living Together & 1 \\
Not Dotermined & 20 \\
\hline
\end{tabular}

We have been impressed by the criticism of certain individuals with whom wave talked that so much secrecy surrounded the adoption procedure, and that, in the eyes of the law, apparently the chief concerm was to protect the inheritance rights of children. From the material collected pertaining to the natural parents, it would appear that the inheritance rights should demand least attention. It would seem to us that the most important thing in the court reports should be to protect the adopted child from the unpleasant facts in his background, unless they could, in some way, contribute to his future security.

${ }^{1}$ See Appendix I for Copy of Adoption Law, Sec. 33lb-8. 
We have come a long way from the feeling that a child will be happy if placed with wealthy parents who can "do overything for him". Much more is taken into consideration. There is an interesting pair of photographs appearing in Dr. W. T. Slingerlend's book entitled "Child-Placing in Pamilies". Under the photographs there is a statement: "A child from this shack went to this fine free home." The shack, apparently, is an humble mountain cabin, and the plcture of the adoptive home is nothing less than a palatial mansion surrounded by 1

rest acreage. The heredity factors as revealed in the social study of the naturel parents predict on what level the child can best particlpate. Our current concepts in child-placement would make us question the edvisability of taking a child from an "humble home" and placing him in a home demanding superior performance and subsequent achievement.

In this chapter wo have attempted to give a picture from tho procurable information describing the natural parents of those children who were adopted in Jofferson County during 1941. Every adoption begins a new adrenture, whlch brings heppiness to some and dissatisfaction to others. Wo shall see in tho subsequent chapters whother the adoption practices have brought about adoptive placements which I1tted each ch1ld, and whether these femily backgrounds were or wore not taken into consideration. Throughout tho study of the natural parents we were aware of the gaps in the information which was

\footnotetext{
1
} Russel Sage voundati on, 1919, p. 142b. 
secured. As skilled practice in adoption becomes more prevalent, this need for pertinent information will, no doubt, be met and secured at the time the child is given up by the natural parents. 
CHAPTHR III

THE CANDIDATE FOR ADOPTION 
CHAPTIR III

THE CANDIDATE TOR ADOPTION

In this chapter thore is discussion of the best standard of adoption to be striven for in planning for the child in need of permanent placement and the locel procedure as was brought out in the atudy of the reports. An examination of the adoption rate, and those aspects of race, sex, age, birthplace, status of birth, and family ties which influenced the making of the respective adoption plans is given. To depict more clearly the dynamies of adoption, there is Interpretation of the necessary steps in the working out of the adoption plans. These steps include the social stady, the physical exanInation, the periodic psychological tests, the use of foster study home, the participation of the child in his ovn placement, and the probation perlod. The advantages of casework service and agency procedure in the attainment of the goal of the best possible standard of adoption for every child are pointed out.

\section{Adoption Rate}

The number of wite children placed for adoption mas almost twenty-five times the number of Negro children placed for adoption. There were seventy-two white children and only three Negro chlldren. The Negro population is 47,158 for Jefforson County and the total of 
the white and forelgn born population for Jefferson County is 1

338,234. The white population is nine times that of the Negro, while the white adoption rate is twenty-five times that of the Negro. Apparently, adoption 18 more genorally accepted by the white race as a method of caring for the child born out of wedlock. Fram our own observation, in a chlld-placing agency, there are notably fewer Negro applications to adopt a child. This, coupled with the fact that the feeling of stigme toward illegitimacy is far less, would help to explain the very low adoption rate. There is the economic level to be considered and adoption fees ranging from twenty to one hundred dollars (with fifty dollars minimum as the recommonded foe by the Jefferson County attorneys) can be afforded only in rare instances by the Negro in the low income group.

The adoption rate for 1941 was 2.16 per 10,000 white population and .63 per 10,000 Negro population, making the total adoption rate for the county 1.97 per 10,000. One-third of the total of two bundred twenty-eight (228) adoptions for 1941 in the ontire state were in Jefferson County.

The adoption rates (per 100,000$)$ in some other atates are

1

${ }^{1}$ Sixteenth Census of the U. S., op. c1t.

Zierified by County Attorney.

3

The total was taken from the Adoption Register, Child Welfare Division, Frankfort, Ky. 
es follow: :

$\begin{array}{lr}\text { Alabama } & 7.6 \\ \text { New Yexico } & 11.1 \\ \text { North Dakota } & 15.5 \\ \text { Minnesota } & 33.7 \\ \text { Rhode Island } & 36.0 \\ \text { Massacmusetts } & 42.9 \\ \text { California } & 43.5 \\ \text { Oregon } & 51.1\end{array}$

In comparison, Kontucky's 1941 adoption rate per 100,000 of 2 its population, $2,845,627$, 18 8.01 . This would place Kentucky's adoption rate betwoen those of Alabama and New Mexico.

TABIE 5

CHIIDREN ADOPTED IN JEIFTERSON COUNTT, KRENIUCKY

BY RACE AND PER 10,000 POPULATION

\begin{tabular}{c|c|c|c}
\hline \hline Race & Children & Population & $\begin{array}{c}\text { Persons } \\
\text { Adopted } \\
\text { Per 10,000 } \\
\text { Population }\end{array}$ \\
\hline Total & 75 & 385,392 & 1.97 \\
\hline Whito & 72 & 338,234 & 2.16 \\
Negro & 3 & 47,158 & .63 \\
\hline
\end{tabular}

Sex of Child

There were forty-seren adoption petitions for girls, exceeding by nineteen the number of petitions for boys. In 1940, for all children registered in Kentucky, there were about four thousend $(4,000)$

1 ${ }^{1}$ Colby, Problems and Procedures in Adoption, op. c1t., p. 4. 2 Verified with County Attornoy. 
more females than males under five years of age; for the City of Ioulsville, only one hundred ninoty-six (196) more females than males 1 under flve years of age; and for Jefferson County there were eightynine more males under five jears of age than females. We bave used the age under five years because there is a preference to adopt younger children. The possible explanation for more girls than boys being adopted is that more often the prospective application for adoption is instituted by the adoptive mother who wants a girl for companlonship, and the lay person more often feels a girl is much easier to rear than a boy. The $\mathrm{g}^{1 \mathrm{rl}}$ is thought of as wanting to stay closer to the home, and therefore would give more satiafaction to the adoptive mother. Wo have observed that prospective adoptive parents. who have waited a long time for a child to adopt, when approached, will accept a boy, if he is arailable. However, if relatives adopt a child, the sex is of little importance, since the main reason for adoption is to give the child with blood relationship an assured position in the family group. A little more than one-third as many girls were adopted by relatives, and only one-sixth more girls than boys were adopted by other persons then relatives. Two and one-half as many children were adopted by other persons than were adopted by relatives. This informati on appears in Table 6 .

\section{Status of Birth}

The status of birth in the serenty-fire adoptlons was dirided Into twenty-geven children who were born in wedlock and forty-eight

1. s. Census, 1940, op. elt. 
TABLE 6

SIAX OF CHIIDRRAN ADOPLED,

BY RETATI ONSHIP OF

PETITIONER TO THE CHIDD

\begin{tabular}{l|c|c|c|c}
\hline \multirow{2}{*}{ Sex } & \multicolumn{2}{|c|}{ Total } & \multicolumn{2}{c}{ Adopted By } \\
\cline { 2 - 5 } & Number & Per Cent & Relat1res & $\begin{array}{c}\text { Other than } \\
\text { Relatires }\end{array}$ \\
\hline Total & 75 & 100.0 & 22 & 53 \\
\hline Boys & 28 & 38.2 & 5 & 23 \\
Girls & 47 & 61.8 & 17 & 30 \\
\hline
\end{tabular}

who were born out of wedloak. If we use the total of one thousand six mundred forty-two $(1,642)$ born out of wodlock for 1938 in Kentucky, approximately one out of every thirty-three children thus born was placed for adoption. There were one thousand one bundred twenty-five $(1,125)$ births out of redlock of white children and fire hundred seventeen (517) births out of wedlock for other races.

\section{Age of Child}

The ages of the children adopted are shown in Table 7. Thirty-one or approdimately two-thirds of the chlldren born out of wedlock were adopted under the age of four years by persons other than relatives. In contrast, seventeen, or very nearly two-th1rds, of the

$I_{\text {Statisticel Abstract of the U. S., U. S. Govermment Bulletin }}$ (Washington, 1940).

2 Ibia. 
children adopted by relatives were over the age of four years. Apparently the rejection upon the pert of the mother of the child speeds her desire to relinquish the child at an early age. About forty-six, or two-th1rds of the children, regardless of the status of birth, were adopted before they were $\mathrm{six}$ years of age. Only six children were fourteen years or over, which is the age at which the adoptee is required to give his consent to the adoption in writing in the presence of the court.

\section{Birthplace of Child}

Seven of the twenty-seren children born in wodlock wo born outeide of Jefferson County in other counties in the state, and one other child in this group was born in another state. Of the fortyelght children born out of wodlock, seren were born in other counties of this state. Six children were born out of wodlock outside the state. A total of seven of the children adopted in Jefferson County in 1941 had birthplace in another state.

\section{Benefit of Cesework Service}

In the examination of those children having casework service 1

In planning, as 18 shown in Table 8, not one child born outside the 2 state had benefit of specielized casework service. Seven of the

1

An Individualized procedure incluaing a thorough exploration of heredity factors, physical condition, Intelligence and personality, plus a conscientious awareness in using those findings to place the chlld in an adoptive home comensurate with his potentialities. 
TABLE 7

ACE OF CEILD AT ADOPIION, BY STATUS OF CHIDD AT BIRTH

\begin{tabular}{|c|c|c|c|}
\hline \multirow[b]{2}{*}{ Age } & \multirow[b]{2}{*}{ Total } & \multicolumn{2}{|c|}{ Status of Child at Birth } \\
\hline & & $\begin{array}{l}\text { Born In } \\
\text { Wodlock }\end{array}$ & $\begin{array}{l}\text { Born Out of } \\
\text { Wodlock }\end{array}$ \\
\hline Total & 75 & 27 & 48 \\
\hline $3-5.9$ mos. & 2 & 1 & 1 \\
\hline $6-11.9$ mos. & 7 & 1 & 6 \\
\hline 1 - 1.9 grs. & 12 & 4 & 8 \\
\hline $2-3.9$ yrs. & 19 & 4 & 15 \\
\hline $4-5.9 \mathrm{yrs}$ & 6 & 2 & 4 \\
\hline $6-7.9$ yrs. & 12 & 6 & 6 \\
\hline $8-9.9 \mathrm{yx}$ & 6 & 2 & 4 \\
\hline $10-11.9 \mathrm{y} \times 8$ & 2 & 1 & 1 \\
\hline $12-13.9 \mathrm{yrs}$ & 3 & 2 & 1 \\
\hline $14-20.9 \mathrm{yrs}$ & 5 & 3 & 2 \\
\hline 21 and Over & 1 & 1 & 0 \\
\hline
\end{tabular}

children borm out of wadlock in other counties of the state had agency assistance in planning, and fifteen children borm in Jefferson County had specialized casework service. In twenty-two of the forty-e1ght adoptions of children born out of wedlock, casework service was given. The Kentucky Children's Home made plens for three children born in Jefferson County, and for six born in other counties of Kentucky. The Children's Agency made plans for nine children born in Jefferson County, alx of whom were delivered in the Susan Speod Davis 


\section{TABIS 8}

CHIIDRREA BORN OOT OF WHDLOCK, VITH OR WITEOUI BETETIT OF AGTACY PLAMIITG, BY BIRTEPLACT

\begin{tabular}{c|c|c|c}
\hline \hline \multicolumn{1}{c|}{ Birthplace } & Total & $\begin{array}{c}\text { Without } \\
\text { Agency } \\
\text { Planning }\end{array}$ & $\begin{array}{c}\text { With } \\
\text { Agency } \\
\text { Planning }\end{array}$ \\
\hline Total & 48 & 26 & 22 \\
\hline Jefferson County & 33 & 18 & 15 \\
Other Counties in State & 9 & 2 & 7 \\
Outside of State & 6 & 6 & 0 \\
\hline
\end{tabular}

Maternity Hone, two at the General Hospital, and one in a private hospital. One of the children bad been referred by the Child Welfare Division for study, foster-homo boarding care, and placement. The Home of the Imnocents planned for one child only, born in a local prirate hospital. This agency, a Commulty Chest affiliate, has as its primary funetion the operation of a temporary receiving home for chilaren and, in rare instances, has placed a child for adoption. AccordIng to Miss Norton, the Brecutive Director, not more than two children have been placed per year for adoption. The Iouisville and Jefferson County Children's Home assisted with two children bom at the Susan Speed Daris Home. The Family Service Organization holped in one situation where the mother later married and adopted her child. The Susan Speed Lavis Home gave only maternity care.

Prior to placement in the adoptive home, an agency had arranged, in eight adoptions, for the mother to be given a psycholog1eal examination. During the inrestigation of the adoption petitions, 
It was verified through the schools that six untested children, before adoption, were adjusting satisfactorily in school. These were six "old adoptive placements" of the Kentucky Children's Home. In one other Kentucky Children's Home Plecement, where the child was adjusting poorly in school, a psychological examination was arranged for that child. The court sustained the recommendation that the adoption be deferred for six months unt Il the caseworker, the adoptive parents, and the school could assist the child to work out a more satisfactory adjustment. This adoption was approved and completed at the end of the six-months period.

In ten of the twenty-two adoptions, the child was born at the Susan Speed Davis Home; in two, at the General Hospital; and in two, at a private hospital.

\section{Length of Probation Period}

In examining the length of time for each case prior to the completion of adoption, it was discovered that the periods of probation varied in length from less than six months to ten years or over. Adverse espects present themselves at each extreme. Although the law states three months as the required period the candidate for adoption 1 is to reside with the petitioners, it is the practice of childplacing agencies with casework functions to require a year's period.

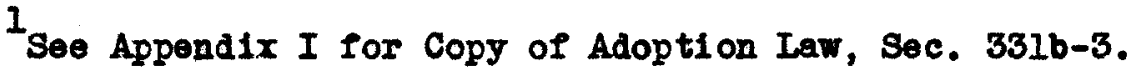
2 The Children's Agency, The Child Velfare Division, and the Louisville and Jefferson County Children's Home are in accord with a year's probation period recommended by the Child Welfare League of America. See Page 19. 
A period longer than a year, unless there is a good reason for further observation, offers a threat to the future securtty of the child, more particularly if the child's status in the home drifts along without definite acknowledgement of the permanence of his role in the femily unit.

For sixteen chlldren there was no placement away from mother. Fourteen of these were adoptions by the mother and the stepfather. One was an adoption by the maternal grandparents when the girl was twenty. She was told at the age of ten that she was not a natural child. This was at the time of her mother's death. One was an adoption by the maternel grandmother and step-grandfather.

Four had been in the adoptive hame less than six months, and two of these children were born out of wedlock and placed by the same attending physician. In one of those situations, the natural mother pald the adoption fee. The adoptive mother had lost her baby at birth three months before at the same private hospital. The mother was told the name of the adoptive parents. In the other situation, the physiclan filled in the birth certificate with an assumed name for the mother. Each mother signed consent to adoption at birth, which is unfair to the mother, because she har hardy in physical condition or in possession of adequate equilibrium to warrant making a permanent decision about the disposition of her child. One child, whose parents

1

${ }^{1}$ Eric Kent Clarke, M. D., Unpublished Dissertation, University of Rochester, "Revolt Against Circumstance", Rochester, N. Y., 1938, p. 108, Dept. of Psychiatry (A Study of 200 Children Who Revolted). "Recognition of adoption seems to be ineritable: consequently, the earlier this knowledge is imparted to the child by the adoptive parents, the smaller the likelihood of conflict." 
were divorced and whose father remarried, was adopted by her mother's cousin, who had cared for her since birth. One child's mother died shortly after the delivery, and the father had four other children being reared by elderly matemal grandparents. He felt he could not ask them to take the fifth child, and placed her with a cousin, the adoptive mother, and her husband. In ten of the adoptions, the child had been in the home from six months to one year. In one of these adoptions, the child was being boarded by The Children's Agency while the unmarried mother was making her decision to keep or give up her baby. After three months, she asked the foster boarding parents if they wanted to adopt the child. Prior to the boarding plan, the foster home had been approved and, fortunately, fitted the child's verified ability (through psychological testing) and the child's temperament.

Eleven children had probation periods of one year to one month less than two years. One of these cases was colored. The adoptive parents passed the mother and baby on the street and took them into their home. The mother later deserted, but was discovered, and gave her consent to the adoption.

Seventeen children, or 28 per cent of those placed, were in the adoptive home three years or over. We would question these lengthy probetion periods if the child had been placed at the age of one year or one and one-half years of age because there was indicated a quality of doubt or indecision about the adoption. This might have been caused by lack of supervision by those having placed the children in these homes, as had happened in some situations because of Iimitations 
in staff and lack of clearly defined adoption procedures. In some instances, children had been boarded in the home prior to the making of an adoption plan.

The court reports did not always indicate the date of change Irom the status of a boarding home to a free home with the intentions of adoption. Iouisville and Jefferson County Uhildren's Hame boarded five of these children in foster homes prior to adoption plans, with the adoptive parents subsequently becoming attached to the children. Family situations varied, from deserting mothers for two children born out of wedlock, to a deserting father with the mother unable to support her three children, an unstable mother who had not seen her child since 1931, the father's whereabouts being unknown, and his parents being dead. The mother, of three children, was fond of the foster boarding parents who had boarded her youngest son since the age of one year and recognized his attachment to them and approved an adoption plan. The Kentucky Children's Home, caring for dependent children comitted to it by county judges, where no other plan can be made, boarded one child whose mother wished to conceal his birth out of wedlock from her four legit imate children. The boarding parents became attached to the child and the adoption plan had the mother's approvel. The Children's Agency, a private agency and Community Chest affiliate, boarded one of these chlldren for a longer period than usual in order to have psychiatric service and approval that she was a good adoptive risk. Her mother was a patient at Central State Hospital. It was verified that the mother's psychosis could in no way be inherited before an adoption plan was approved. 
For $1 x$ of these children there were periodic psychological exem inations to rerify intelligence for use in determining the matchIng of future placements for them.

For the eleven children in the adoptive home for four years or over a description is given. One of these children was registered by the family physician as the natural child of adoptive parents. The scene was laid at night and the child, at the age of two weeks, was taken to the home of the adoptire parents who had arranged for the deception. According to the court report the child is never to be 1

told he is adopted. This child was born in another county of this state. When the adoption petition was investigated, worker requested a physical exemination, and it was revealed that the child was syphi1itic. Ho is receiving treatment. Adoptive parents were grateful for the knowledge and expressed eppreciation of the worker's casework serrice in bringing it to their attention.

One child was a "foundling", giren to adoptive parents by a county judge in another state, when the adoptive father was visiting his "place of birth". The child had been loft at the county hospital. Two of these children were nineteen years of age. One became aware he was not a natural child in June, 1941, when he sought employment and needed to secure a birth certificate. Ho was told of his motbor's death in chlldbirth, and at that time he had beon given by his father to hts second cousin, the adoptire mother. The boy hed been taught to belleve his two older brothers were his cousins, although they knew he 
was their brother, and his father was thought by him to be his uncle. The father and the boys' brothors lived in another clty, but had risited annually in the adoptive home. This boy requested adoption to give him the legal right to the noms he was using and wanted to continue to be known as the natural child of the adoptive parents. In the process of the adoptive investigation, the worker learned that the adoptive parents" own son, ten years older, considered a "moron" by references, had been a disappointment to them. He was away erom the howe, haring enlisted in military service. The caseworker visited adoptive parents' references and did not divulge her real purpose, using as her roason for contact, the possibility that these parente were considering boarding a boy in their home. The adoptive home was considered an excellent one.

Another child, a boy of nineteen, was ono of two children whose father had deserted. The mother kept the older bogs, and scmo interested friends told the mother about the adopt1ve parents, who hed one daughter, s1x, and wanted a son. The boy was placed at the age of one and one-helf years. He was not told he was adopted unt1l he was 1 fourteen, but seemed to accept it rery well. Caserorker noted that he had an irregular school record and apparently had been unable to adjust on the high cultural level of the adoptive parents. Beconing dissatisfled with school, he had recently secured a job as a messenger boy. Adoptive father was a high school graduate and a successful business executive. He showed some disappointment in the boy's achlevement, but hoped "he will do better".

\footnotetext{
$1_{\text {see footnote p. } 64 .}$
} 
Still another adoption was that of a boy thirteen and one-half years of age. He has always known he was adopted, but is accepted "on the outside" as a natural child. In 194l, the adoptive parents arranged for the adoption to insure the boy's legal right to inheritance, as well as the use of their surname. Adoptive father is a college graduate, and has a $\$ 3,000.00$ policy to be spent for a college education for this boy whose school adjustment thus far is only average.

The distribution of these children in relation to their probation periods appears below in Table 9.

TABII 9

LENGTH OF TINE CHIIU ITVRU

IN AWOPTIVE HOMNE PRIOR

TO GRAWIING OF ADOPTION

\begin{tabular}{|c|c|}
\hline Length of Time & Number \\
\hline Total & 75 \\
\hline No Placement & 16 \\
\hline Less than 6 mos. & 4 \\
\hline $6 \mathrm{mos}$. to $1 \mathrm{yr}$. & 10 \\
\hline $1 \mathrm{gr}$. to $1 \mathrm{yr} .11 \mathrm{mos}$. & 20 \\
\hline $2 \mathrm{yrs}$. to $2 \mathrm{yrs}$. $11 \mathrm{mos}$. & 8 \\
\hline $3 \mathrm{yrs}$. to $3 \mathrm{yrs}$. $11 \mathrm{mos}$. & 6 \\
\hline $4 \mathrm{grs}$, to $4 \mathrm{grs}$. 11 mos. & 2 \\
\hline $5 \mathrm{yrs}$. to $10 \mathrm{yrs}$. & 6 \\
\hline Over $10 \mathrm{yrs}$. & 3 \\
\hline
\end{tabular}




\section{Age at Time of Placement}

When we considered the age at the time of placement, the distribution of cases placed by agency and those placed Independently reflect the past philosophy of the community service given in adoption. All institutions were included under the heading of agency, whether facilities for a casework program were or were not in operation. At present, The Children's Agency is the only private agency giving casework service in child-placing, and the Kentuciry Children's Home and the Loulsville and Jefferson County Children's Hame are the two public agencies giving this service. 1

The children born in wedlock were older when placed, possibly due to the family break-downs occurring at a later period. The ages of the fifty-nine children lomitting fourteen adopted by the natural mothers and the two adopted by the maternal grandparents) at the time of placement for adoption are given and described below. We also differentiated between agency and Independent placements.

The six of the serenteen children born in wedlock were placed by an agency when they were six years or over: three from the Louisville and Jefferson County Children's Home for dependent children; one from the Kentucky Children's Home with a similar function; one from the Christian Orphans Home; and one from the All-Prayer Foundings Eome.

1

These agencles have a staff of technically trained caseworkers, case supervisors and executire directors. Their standards are those of the Child Welfare League of America. 
Thirty-fire of the forty-olght children born out of wedlock were placed by an agency or institution. The fire children placed before the age of one month were three from the Kentucky Children's Home and two from Our Lady's Home for Infants. Two of the Kentuck Children's Home placenents wero made nine years ago and one was made six years ago, before that institution had a casework program, or prior to its being pleced under the supervision of the Child Nelfare Dirlsion, State Department of Public Welfare. The two placements of Our Lady's Home for Infants were made in 1940 and 1941. Since physiclans are virtualiy in agreement that a period of at least three to six months is needed for a mother to recover her physical atrength, and an umarried mother certainly needs more time to recover her equilibrium, it is questionable that mother should be asked to make a final decision about the disposition of her child before the child 1s three months old. A reasonable period of time is needed to study the background and development of a child in order to know what kind of an edoptive placement to make. Miss Mary Ruth Colby of the United States Children's Bureau questions whether any chlld should be con1 sidered for adoption under the age of four months.

Seven children under three months of age were placed for adoption, from Our Lody's Home for Infants. Of the thirty-fivo children born out of wodlock, Our Lady's Home for Infants had placed twelve: eleven of them were undex the age of $81 x$ months, and one was between

${ }^{1}$ Colby, Problems and Procedures in Adoption, op. clt., p. 28. 
the ages of one and two months.

It is questionable whother a valid study of a candidate for adoption can be made in the comparatively short period of study and observation of these children. While the adoptive parents exert pressures in order to get a young chlld, it is fairer to the adoptive parents to walt until the child's capabilities and behaviour can be more prodictable. Child-placing agencies are set up to care for the needs of the child, their client, rather than for the omotional neods of the adoptive parents who have falled to have children of their own. A longer period before the placement will give time to help the adoptive parents explore their motives and express their expectations of the child. It is the responsibility of the casoworker to place a child in the adoptive home which will neet the demends of that particular child. The disciplined training of the caseworker to maintain an objective att1tude makes it possible to individualize the adoptire parents and to see more then a couple with generous impulse to "tako a child and care for it", as it is so often expressed by references when visited by the ceseworker.

Seven children who were born out of wodlock were placed by The Children's Agency: one at six months; two at nine and eleven months; one at eighteen months; and one each at two and one-half years, three, and three and one-half years. All of these children

1

Since making this study, we have talked with Father Lammers, Director of Our Lady's Home for Infants. It was learned that a plan is contemplated to have the children given psychological examinations before placement, and only recently the use of two or three foster boarding hanes has been initlated, in an effort to raise the institution's standards of adoptive placement. 
were giren more than one psychological examination. One superior child was given five psychonetrics. With an average of the periodic testing regults the agency could place that child with a maximum of assurance, In a genuinely superior adoptive home, to which he was entitled. In six of these placements, the mother was given a psychological examination for use in evaluating the heredity background and its relation to the predictability of the performance of her child. These are important and available techniques in adoption. While the procedures are time-teking; they are necessary if placements are to be made with confidence.

Two children under four years old, of unmarried mothers, wero placed by the St. Thomas Orphanage.

The All-Prayer Foundlings Home placed one child under one 1 year, and one at one and one-helf years of age.

The Home of the Innocents placed only one child lat the age of eight months). This child had been given a psychological examination.

Those children of unwed mothers, placed independently of an agency, through the attending physician, incl uded two at the ages of ten days and six weeks. The remaining ones were placed by the mother of the child.

Mr. G. C. Cromer, Director of the All-Prayer Foundlings Home, stated be thought psychological examinations were atill in an experimentel state. Therefore, he had not used them except when the adoptive parents had requested a mental test. He had placed over nine bundred (900) babies in his.thirty-seren years of experience, and if a chlld appeared retarded he held it a longer time than usual, for his own observation or until the child "grew out of it". The Child Welfare Division had offered the facilities of its Staff Psychologist. He planned to use this service when he was asked for a chlld's mental rating. If adoptive parents requested, he also arranged for vene real tosts of the candidate for adoption. 
Information relative to the age of the children at the time of placement is contained below in Table 10.

TABLE 10

ACE OF CHIID AT TIME Or

PLACRMARVI IN ADOPIIVE HOME, BY STAIUS OF

BIRTH AND TYPE OF PLACIRMENT

\begin{tabular}{|c|c|c|c|c|c|}
\hline \multirow[b]{4}{*}{$\begin{array}{l}\text { Age of Child } \\
\text { at Time of } \\
\text { Placement }\end{array}$} & \multicolumn{5}{|c|}{ Children Placed in Adoptive Homes } \\
\hline & \multirow[b]{3}{*}{ Total } & \multicolumn{4}{|c|}{ Status of Birth } \\
\hline & & \multicolumn{2}{|c|}{$\begin{array}{l}\text { Borm In } \\
\text { Wedlock }\end{array}$} & \multicolumn{2}{|c|}{$\begin{array}{l}\text { Borm out of } \\
\text { Wodlock }\end{array}$} \\
\hline & & $\begin{array}{l}\text { Placed } \\
\text { by } \\
\text { Agency }\end{array}$ & $\begin{array}{l}\text { Placed } \\
\text { Independ- } \\
\text { ently of } \\
\text { Ageney }\end{array}$ & $\begin{array}{l}\text { Placed } \\
\text { by } \\
\text { Agency }\end{array}$ & $\begin{array}{l}\text { Placed } \\
\text { Independ- } \\
\text { ently of } \\
\text { Ageney }\end{array}$ \\
\hline Total & 59 & 10 & 7 & 35 & 7 \\
\hline Onder 1 mo. & 9 & 0 & 1 & 5 & 3 \\
\hline 1 mo., under 3 & 10 & 1 & 0 & 7 & $\mathbf{2}$ \\
\hline 3 mos., under 6 & 8 & 0 & 3 & 4 & 1 \\
\hline 6 mos., under 1 yr. & 7 & 0 & 0 & 7 & 0 \\
\hline $1 \mathrm{yr}$, under 2 & 7 & 1 & 1 & 5 & 0 \\
\hline 2 gre., under 4 & 9 & 2 & 1 & 6 & 0 \\
\hline 4 yrs., under 6 & 1 & 0 & 0 & 0 & 1 \\
\hline 6 grs. or over & 8 & 6 & 1 & 1 & 0 \\
\hline
\end{tabular}


Consont to Adoption

Consent to adoption was given by the mother in thirty-seven or in 49 per cent of tho adoptive placements. One of these children was placed for adoption by the Home of the Innocents. Eight children were placed independently by the mother: one with maternol grandparents to be reared as a natural child, and one with a foster boarding mother; two through the attending physician; one with relatives, on through the maternal aunt who 11 ved in Louisvillo and knew "scmeone who wanted a child", one with mother's former nelghbors who had moved to Iouisville; and one, nine years ago, through the Kentucky Children 's Home Society, of which the mother was a ward. Her child had not been comitted to that instituti on.

This last placement was somowhat strange. It had boen arranged for the child to be placed whlle the husband was away on a business trip. The adoptive mother decelved her own mother and ald not tell her the true eircumstences until she had dirorced hor husband, who fought to gain legel custody of the child he thought was his own. Later this adoptive mother remarried, and her second husband's rolatives thought he was adopting his wife's own child by a former marriage. The Caseworker explored this deception with the adoptive mother, who recognized that the situation might prove hazardous if the child later discovered the truth. However, the child thought she was the notural child of the adoptire mother and was apparently socure.

1 See footnote, p. 64 . 
References on the adoptive mother described her as refined and of alightly high-strung temperament. The adopt1ve father was understanding and accopting.

Twelve of these children were adopted by the own mother and stepfather. The mother became a party to the petition. Duration of married life of the mother and step-father prior to the adoption procedure varied, as follows: five months, nine months, one and one-half years, four years, five years, four for six years, and two for ten years.

Thirteen of the children for whom consent was given by the motber were placed for adoption by Our Lady's Home for Infants. Three of the children were born outside of this state. Arrangemonts for maternity care were made, in most cases, in private Roman Cathollc hospitals. Apparently it was not the procedure to have the mother appear in court and have her child legally comitted to this institution for planning, since in no instance had there been a commitment to the Institution.

Three of the mothers placed their children for adoption through the All-Prayer Foundlings Home. In one situation, the director of this institution was of the opinion that the Rolinquisment of Parental Control and Consent to Adoption paper was part of his permanent record on the child, and, in one case, it was necessary for the county attorney to 1 ssue an order for the paper to be submitted for filing with the adoption petition. One of the chlldren had a defective eye. One ch1ld, when referred for a psychological examination during the edoption investigation, was rated "average". The child's mother 
had been rated as a high grade moron prior to her abrupt departure Irom the Susan Speed Davis Maternity Home. It would have been helpful to observe this child for some time before placement to determine the lerel of adoptability with a more acceptable degree of validity. Only one consent to adoption was jointly given. Those parents gave the child for adoption (following the Ohio River Flood Disaster, 1937) to a maternal uncle, "who had two boys and wanted a girl". The parents had one other child, and for economic reascons made the adoption plan.

Three children given by the father for adoption following the mother's death. In one case, the worker making the required investigation verified the cause of the mother's death as tuberculosis (eleven days after the child's birth), and adoptive parents were grateful for this knowledge, which they had trled unsuccessfully to secure. Adoptive parents were cooperative with the Board of Tuberculosis Hospital Clinic in securing tests, and that clinic promisod follow-up care. The caseworker also cleared this child's birth record, which had been filed incorrectly at the hospital because of the mother's having registered under the name of the alleged father rather than her own name. In another case, the father boarded in the home of adoptive parents and was addressed as "uncle" by his child. His niece was the adoptive mother, who had cared for this child since the death of the mother in delivery. The father had two older children, cared for by the maternal grandparents. In the third case, the father had been known to rellef agencies, and, following his wife's death, he had gone to the home of the maternal grandparents, where he boarded his 
four older children. He rejected his last born child, associating the chlld with the cause of the mother's death. The Uhildren's Agency had known the adoptive home as a foster boarding home, and the adoptire parents had been rated as "excellent substitute parents" for boarding children.

Four adoptees, 16, 19, 20, and 21 years of age, since they were over 14, were required, according to the adoption law, to give consent to their respective adoptions. One was being adopted by a non-relative, and this was the only situation where there was no adoptive father. Adoption was approved in order to give permanent securIty to this girl who had lived in the adoptive home prior to the death, three years before, of the adoptive father.

There were seven Juvenile court commitments, and one was to The Children's Agency. The one was the child of a Negro mother, who had died while she was a patient at the Central State Hospital. The child had been referred at birth to The Chilaren's Agency for planning. The relatives refused to see the child or to accept eny responsibility for her. The foster boarding parents became attached to, and wented to adopt, the child, who was nearly 4 years of age. The Children's Agency had made a dependency filing in the Jurenile Court to secure legal custody. Both the psychiatriat at the hospitel for the mentaliy ill and the psychiatrist at the Mental Hygiene Clinio approved this child as a good adoptive risk. The psychological examination had rated the child as "above average" in intelligence.

Two children had been comitted to the St. Thomas Orphanage. It was difficult to understand why one of these children had a long 
Institutional experience of ten years before he was placed for adoption. The reason which was given to the caseworker who made the inrestigation was that a "high type" home was wanted to fit this child. This delay was questionable, when so many applications for children are on flle in other agencles, many of them by Romen Catholics. The mother had had no contact with the child since leaving the maternity home. In the second situation, the mother had returned to live with the alleged father. There was no evidence of casework service in an effort to establish legal paternity or secure support for this child. Four of the Juvenile Court Commitments were for dependent children to the Louisville and Jefferson County Children's Home (Ormsby Village). The parents of two de no effort to keep up any contact with these children. One parent died, and one was a patient in Central State Hospital, and the father had two older children. He was in accord with an adoption plan. All of these children were given the benefit of testing service by the staff psychologist to ascertain the level of adoptability.

\section{Court Commitments}

A diference in classification of court commitments was made because the children in Jefferson County are comnitted through the Jurenile Court, while in other counties of the state commitments are made through the County Court. Of the ten County court conmitments, two were to the Christian Church Orphans Home of Louisville; five were for children committed to the Kentucky Children's Home, Lyndon, Kentucky, now under the administration and the supervision of The 
State Department of Public Welfare; one was a commitment to The Child Welfare Division of the State Department of Welfare; one was a commitment to the county judge, who placed the child directly; and the last one was a child from Tennessee, where the county judge gave legal custody. The counties which were represented were Bracken (2), Clark, Larue, Letcher, Mercer, Monroe, Pulask1, and Taylor.

There were eleven adoptions in which the consent was given by the agency or institution having both the Relinquishment of Parental Control and Consent to Adoption paper signed by the mother, and a commitment by the court. The Children's Agency gave consent to five adoptions. In four cases, the mother had appeared in court at a private hearing and asked that her child be committed to The Children's Ageney for an adoptive plan. In another case, the mother had left the state, and a dependency filing was made. Efforts were made to locate this mother shortly before the adoption. The chlld had been in the adoptive home for tive jears. The Agency had stood by, while the prospective adoptive parents recovered from materfal losses suffered during the Ohio River Flood Disaster, and until the adoptive parents were ready to complete the adoption.

An accepted tenet of casework is that the client should be allowed to participate in the planning. The mother's declaion becomes meaningful and gives evidence of some morement or active participation in the decision of giving up her child if, in addition to signing the release for adoption, she has roluntarily appeared before the judge and requested an adoption plan.

In another case, The Children's Agency approved the adoption 
by a foster mother of a child to whom she had given boarding care. The Child Welfere Division gave consent, following the mother's signed release and legal comitment to that public agency by the county judge in the community of the mother's legal residence. The Children's Agency had been supervising the child in the foster boarding home, at the request of the Child Welfare Division.

In two adoptions, the children had been committed as dependents to the Kentucky Children's Home. 'I'hree children were committed as dependents to the Loulsville and Jefferson County Children's Home. The relatives were consulted and gave consent to adoption. Although this is not legally necessary following legal comitment to an 1 institution, it is part of a casework procedure as administered by 2 that public agency, and doubly safeguards both the adopted child and the adoptive parents. There were three other cases, one in which a trust company was statutory guardian, one in which a Public Administrator and Guardian was appointed to give legal consent (for this child, born in another state, the mother's name had been withheld at her request) and the third, in which the child was colored. This last situation differed from all others studied in that the alleged father was seen by the caseworker while she was making the investigation. The alleged father voluntarlly admitted paternity and had, when first interviewed, wanted to marry the mother and make a home for his child. Howerer, he faced realistically the fact that the mother had a well-

1 Verified by the County Attorney. 2 Verified by the Case Work Supervisor. 
set pattern of beheriour instability and would, because of her drive for excitement, prove unsatisfactory as a mother. Although legal paternity had not been established, and the mother's consent to the adoption would have been all that was necessary, the adoptive parents, who knew the alleged father, had asked that his consent be secured. These figures can be seen in Table 1 .

TABLE 11

PERSONS OR AGUNCY

GIVING CONSTHT FOR ADOPTION

\begin{tabular}{l|c|c}
\hline \multicolumn{1}{c|}{ Consent Given By } & Number & Per Cent \\
\hline \multicolumn{1}{c|}{ Total } & 75 & 100.0 \\
\hline Yother & 36 & 48.6 \\
Mother and Father & 1 & 1.3 \\
Father & 3 & 4.0 \\
Adoptee & 4 & 5.2 \\
Juvenile Court Commitment & 7 & 9.2 \\
County Court Commitment & 10 & 13.2 \\
Relinquishment Papers plus Legal \\
Commitment
\end{tabular}

Period of Residence Prior to Adoption

The court reports gave the following information concerning the length of period of residence following placement. For purposes of clarification, in situations where the mother 
and stepfather have adopted the natural child, the length of the period following the marriage and prior to the grant of the adoption decree has been used. It can be assumed that each child is entitled to know, and be known by, the step-father before an adoption is consummated.

Younger children are usually preferred for adoption; therefore, it is easily understood that the largest number adopted by persons other than relatives would center around the group of forty children under three years of age, or 74 per cent of the total adopted by other persons. The relatives adopted fourteen children over three years of age, or about 63 per cent of those children accepted by relatives.

of five children in an adoptive home for less than six months wth other than relatives, two were placed through the unmarried mother's physician. One was given by the mother to the foster boarding mother while a caseworking agency was assisting the mother to come to a decision about a permanent plan for ber child. In this case, the child was given a psychological examination, and the mother cooperated by being tested. The evaluations of the boarding home, the mother's background, and the child's indicated potentialities were well matched and the adoptive placement was approved. The only apparent disadvantage was that the mother would know the location of her child and might return as a threat to the security of the child. Howerer, the adoptive parents accepted this liability and felt that the mother was sincere in wanting to remore herself permanently from the life of the child, who had adjusted satisfactorily to these adoptive parents. 
One child was placed with friends by the father. The mother had died In childbirth, and the father felt he had developed no ties to this child as he had to his four older children. The fifth situation bad to do with placement of a child by the mother with her cousin, the adoptive father. The parents were divorced and the father had remarried, left the state, and had not contributed to the support of his ch1ld.

On the besis of approved placing methods, including the recommended length of probation or adjustment periods, we question the advisability of the consummation of adoption as early as was the case in nineteen of these adoptions, where the cendidate was in the adoptive home for less than a year. Table 12 indicates the period of probation for each of the children whose court report was studied.

The act of removing a child from the home he has grown accustomed to is a threat to his security which is warranted only in cases of physical abuse and extreme cireumstances. Therefore, the greatest possible care and precision should be had before making the adoptive placement. This would mean a study of all that is related to the child, the verification of factors in his heredity, plus his ability to adjust in the foster home during the temporary study period. With these findings, the final placement for adoption may be made with assurance. This is the advice of genoticists as well as the psychiatrists who are speclalists in heredity and beheviour.

1

See footnote, p. 19. 
TABIS 12

\section{PERTOD OA RESIDENCE OF CHIDD \\ IN ADOPIIVE HOMR PRIOR TO \\ GRANT OT ADOPTION DECRHE, \\ BY RRLATIONSHIP OF \\ CHIID TO ADOPTIVE PARETISS}

\begin{tabular}{|c|c|c|c|c|c|}
\hline \multirow{3}{*}{$\begin{array}{l}\text { Period of Residence } \\
\text { In Adoptive Home } \\
\text { Prior to Grent of } \\
\text { Adoption Decree }\end{array}$} & \multicolumn{5}{|c|}{ Children Who Were Adopted } \\
\hline & \multirow[b]{2}{*}{ Total } & \multicolumn{3}{|c|}{ By Relatives } & \multirow[b]{2}{*}{$\begin{array}{l}\text { By Otber } \\
\text { Persons }\end{array}$} \\
\hline & & 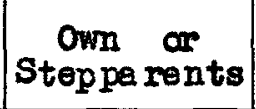 & $\begin{array}{l}\text { Grand- } \\
\text { parent } 8\end{array}$ & $\begin{array}{c}\text { Other } \\
\text { Relatives }\end{array}$ & \\
\hline Totel & 75 & 14 & 2 & 6 & 53 \\
\hline Less than 6 mos. & $\eta$ & 2 & 0 & 1 & 4 \\
\hline 6 mos., less than $1 \mathrm{yr}$. & 12 & 1 & 0 & 1 & 10 \\
\hline $1 \mathrm{yr} ., 1$ less than 3 & 28 & 1 & 1 & 1 & 25 \\
\hline $3 \mathrm{yrs} ., 10 s \mathrm{~s}$ then 5 & 12 & 4 & 0 & 2 & 6 \\
\hline 5 yrs. or more & 16 & 6 & 1 & 1 & 8 \\
\hline
\end{tabular}

Genetics and Psychological Tests

Dr. G. M. McKinley states that feeble-minded children owe their defect to hereditary fectors, ruling out obvious accidental causes - meningitis, syphilis, and glandular imbalance. Superior mentality comes Iram superior lines, in general. Geniuses are apparently never the offspring of mentally deficient parents. Dr. McKinley adds that poor nurture will prevent the best genetic assortment from appear ing. What offers better opportunity than the foster home, giving good physical care to allow for the derelopment and the study of the candidate for adoption? No doubt this is necessary before the agency or 
others can assume responsibility for selecting an adoptive hame commensurate with the child's capabilities.

Moreover, the geneticist stresses knowing the background well enough to rule out possible nervous disorders and epilepsy. Dr. MeKinley added that an epileptic parent will produce an epileptic child in one out of ten chances.

The psychologist with specially prepared tests can, with a series of periodic examinations of the very young child, predict with some assurance what that candidate for adoption might accomplish in an onviroment which offers sustenance or nurture to his soclal and emotIonal needs.

Miss Dorothy Kern Hellowe11, Consulting Psychologiat for two agencies doing child-placing in Philadelphia, Pennsylvania, completed a study of two hundred fifty cases. She was fortunate in being able to follow up the children tested at one, two, and three years; in later years from five to thirteen. It was interesting to note that these children subsequently tested higher in accomplishment. She stated that feoble-minded children can be diagnosed on the first examInation, but superior children can be recognized only in about half the cases when the child $1 \mathrm{~s}$ under three years. Her reas on for the latter was that the meagurement tests developed thus far are lackine in means to evaluate the verbal abllity of the child before language has emerged. She felt her findings were resssuring and definitely

1

G. M. Makinley, M. D., "Genetics in Child Adoption", Child Welfare League Bulletin (New York, N. Y.: Child Welfare League of America, Mar. 1940), V01. XIX, No. 3, p. 3. 
concluded that psychological tests have a real predictive ralue.

No doubt, these tests are raluable in reducing the denger of over-placing and under-placing in adoptive homes, the frequent cause of maladjustment in the later life of the chlld. More concretely, the social worker can use them in a situation where adoptive parents are college graduates and, traditionally, would want their children to attend college. The psychologist would tell us that only the ouperior chlld could do college work without difficulty; the average child, high school work; and so down the scale.

\section{Cesework Service}

By specialized casework service in a chlld-placing agency, we mean the use of an approach and procedure which individualizes the candidate for adoption to the greatest possible extent to ascertaln that child's level of adoptability. By adoptability, beyond legal release for adoption, is meant a reasonebly clear beredity, essentially sound physical equipment, normal mentelity and an emotional 2 capacity for an adoptive relationship. To ascertain adoptability, a scientifically planned procedure is needed to verify heredity factors, to bave the child experience the relating of himself to substitute parental love objects in the foster study home, and to relate himself to the caseworker. The paycholog st interprets the be redity from the

1

Dorothy Kern Hallowell, "Val 1a1ty of Mental Tests for Young Children", The Pedagogical Seminary and Journal of Psychology (Provincetown, Yass.: The Journal Press, No. 2, June 1941), pp. 268288.

2 B1shop, ㅇ‥ c1t., p. 16. 
social history gathered by the caseworker, and this, plus, not one, but several psychological examinations at periodic intervals, helps to validate the level of performance which might be expected of the candidate for adoption.

Acceptance of the bellef that there is a need to study the candidate for adoption in order to place him scientifically in that environment in which he will best function, indicates that the logical place for the preparation to be provided is in a well functioning child-placing agency. If and when the time comes, the mother who wishes to plen adoption for her child is by social pressure or direction referred to a licensed agency doing adoption, the study and preparation would consist of the standard described below.

(a) There is acceptance of the child by the agency for a foster home boarding plan for the period necessary to determine the level of adoptability. The duration of study varies with the child.

(b) A series of periodic physical examinations by a pediatriclan to give feeding advice and supervision, plus necessary innoculations, would be started.

(c) At the age of six months, a series of quarterly psychological examinations would be initiated, depending upon the physical condition of the child (in all faimess to him) to make a valid examInation of his behariour.

(d) The worker and foster mother would observe the child for signs of development, such as dentition, walking and language develop-

The new adoption law does not provide for the licensing of child-placing agencies. 
ment. Play is observed, to, for evidence of bodily coordination. In addition to the opportunity in the foster study home for observation of basic personality traits of the child with subsequent interpretation to evaluate the introvertive or extravertive tendencies, the foster study home provides an opportunity for development of the child's affectional attitudes, with the absence of any feeling of rejection which might be encountered, should the child have remained with his own unwed mother, who, unconsclously, in her physicel contacts with that child, might have rejected him. The experience of forming satisfactory love ties with the mother object and the receiving of satisfactory responses fram that mother object in the foster study home forms a base on which the child is to build his future social relationships. The completion of a satisfactory experience, the serering of foster home ties, followed by the new relationships in the adoptive home, cen be expected to develop with little or no discomfort. During this time, the unwed mother of the candidate for adoption has had an opportunity, freed from any direct relationship with the child, to explore her own feelings about relinquishing parental control and giving consent to adoption. Certainly, in a nation preoumably concerned with the mental welfare of its citizens, the unmarried mother is entitled to this privilege, in order that she may go on living her life with the derelopment of her best possible usefulness, without the necessity of increesing her feelings of gullt at giving up her child. The paying of all; or a part of, foster home board to the agency may be a source of satisfaction in later years to the own mother, who is happy to know she supported a plan long enough 
to secure the best intereste of her child and an adoption plan which "fitted" hin.

Possibly the most important step of all is the opportunity given to the rery young child to participate in his own placement, described in such a feeling way by Miss Marian R. Gennaria, who interprets the procedure with a very young child who is being placed for adoption. Miss Gennaria was a senior visitor at the Children's Bureau at Philadelphia, and describes minutely the steps by which a child worked through a placement to the point where he could go off to a new home, the adoptive home, positively oriented toward it. Since much of the inevitable fear associated with such an experience had already been dealt with by the caseworker and the foster mother, who had prepared the child by repeating in pleasant tones, over a period of time, the nows of the planned rialt to meet the new "Mara" and "Daddy", when the worker showed this candidate for adoption in her office to the prospective adoptive parents, the experience was a pleasent one, and scmetime later the child wanted to go with the new "Mema" and the new 1

"Daddy". The ch1ld was not upset by nights of crying, which would have caused much anxiety to the adoptive parents, crippling them at the very point when everything they had was noeded to initiate the new experience, which should begin on a very sound basis of mutual approval. The process of "getting acquainted" through visits of the child to the agency to see the new Mama" and the new "Daddy", and the return each

1

Marian R. Gennaria, "Helping the Very Young Child to Participate in Plecement", The Joumal of Social Nork Process (Philadelphia, Pa.: The Centaur Press, Philadelphia school of Social Work, 1940), Vol. III, No. 1, pp. 29-59. 
time to that which is known, the foster boarding parents, enables the child to build up in his mind the subsequent change to the adoptive 1 home, with a feeling of pleasant expectation.

No matter how carefully the adoption worker may have paved the way for the chlld with the adoptive parents, nor how well prepared the child mey be for his new relationship, it soon becones evident that no preveration can take the place of the actual experience in building up new relationships. After the placement, strong feelings on the part of both child and adoptive parents may come to the surface, for both may be fearful, as well as eager, to go forward. Many adjuetments are not unlike those which any human being formed. In some adoptive families, content and secure in themselves, affection and lore and respect for each other is built up, quite unconsciously and simply. Others achleve family unity by a step-by-step development. Those who believe that, after a child is placed in adoptive home he will live happily ever after are simplifying life absurdly. Adoptivo parents, in the early period of accepting a candidate for adoption into their home, do need help of a skilled nature, which explains our enphasis on the need for the probation period, supervised by a professional social caseworker.

During the probation pertod, which really means the period of getting acquainted while confidence is gained, reassurance is given that the new relationship may grow into a permanent one. The adoption worker, in making her atudy of the adoptive home, has, we hope, been

\footnotetext{
${ }^{1}$ This procedure has been used with success in The Children's Agency.
} 
accopted as a friend of the adoptive couple. Because of her training In the significance of behaviour, she will knom when to participate actively in helping the family or the child or both through difficult times and when to stand firm in doing nothing except to reassure the family as to their own ability to deal with problems. Since situations and Individuals vary so tremendously, the frequency and the nature of the caseworker's supervisory visits must of necessity be flexible. Because the agency assumes some basic responsibility when it places the child in the adoptive home, it remains in a very unique position to gite help. The agency's chief function may be to withdraw relatirely soon, or it may be wise to continue to give some supervi1 sion and aid over a period longer then a year. Adoptlye parents are encouraged to articulate any rejection of the child, and it is explained to them that, if the child does not "fit", there are other children who might well profit by their home.

Following the probation period, when legal adoption is completed, the adoptive parents, in many instances, roluntarily keep in contact with the agency, partis for advice in case of difficulties and partly to share their joys. The agency is an impersonal source of help and the caseworker, who is removed from the tle to the background of the child, may, with all freedom, be approached by that child, as has been done, particularly when the adopted child has reached adolescence and has begun to think of the questions, Who am I, and if this is not my real home, why was I pleced here?" If valld affectional

lora Pendleton, op. cit. 
tles have been formed with the adoptive famlly, thege questions are resolved with little or no difficulty. The Children's Agency has mot with cooperation from adoptive parents in continuing annual psychological examinations from the ages of two to five or until the adopted child enters school. The adoptire parents have felt a satisfaction in being able to contribute to this aspect of research to deternine the rellability of intelligence testing. It is always a gratification for them to know that the adopted child has progressed to a higher level of participation since being placed in their home. What could be more ideal than having the child-placing agency act as a repository for the confidentlal records of the child and his background, and the caseworker, with her finely developed skills, dispensing the information which the adoptive parents desire when the best possible constructive interpretation can be given. With skilled child-placing procedures, there is rarely a "returned child" to the agency, but knowing that at any time during the probation period that this can be done offers a unique opportunity for the adoptive parents to be free in making their finel decision, of parmount interest for the welfare of the candidate for adoption.

In this chapter we have discussed the best standard of adoption and the local procedure. There was interpretation of the necessary steps: the social study, the physieal examination, the periodic psychological tests, the use of the foster study home, the participation of the child in his own placement and the probation period.

Because of the time limit, adequate social study and exploration of the candidate for adoption was hardly possible to give us the 
seren children placed under the age of three months or to the eleven placed between the ages of three months and under six months. Therefore, elghteen of the seventy-fire children would have benefited by further exploratory study.

Two or more psychologicel tests should be given at periodic intervals of three months, usuelly beginning when the child is six months old. Wo should like to recomend that no child be placed under the age of six months and that it is preferable to wait unt1l the age of nine months or one year is reached, before making the permanent placement. This would mean thet the candidate for adoption would be around two years of age when the final legal step was completed in the adoption procedure. Some children might require even longer periods, deponding upon the need for ruling out any unfavorable hereditary factors through extended obseryation in a study home. A longer period of exploration for the candidate for adoption would allow for the unwed mother to have ample time to make her declsion of relinquismment of hor child.

We should like to recoumend the making of a psychological examination of the mother of the child. There were psychological findings on only twelve of the forty-eight unwed mothers and none on the wedded natural parent or parents to use for evaluation in relation to the child's prodictable level of abllity.

Fifteen of the serenty-firo chlldren were in the adoptive home for 1088 than a yoar. These were adopted by persons other than relatires where it is apparent there is the greater need for proceeding without any eridence of haste. 
There is positive eridence of the need for extending the adrantages of casework service in the early stage of adoption planning If the goal of the best possible standard of adoption is to be attained. 
CHAPILR IV

THE ADOPTIVE PARENIS 
CHAPTER IV

THE ADOPIIVE PAREYTS

In this chapter it is planned to give some description of the standard agency procedure in the investigation of the suitability of the adoptive home, interpretation of the dymamica of the agency relationship with the adoptire parents and to define the meaning of security in the light of the ability of the adoptive parents to give the child a feeling of belonging. Those factors which enter into the matching process of the child with the adoptive parents, namely, the age, formal education, duration of married life, other members of the family, economic status, and the motives for adoption as were found in the local procedure are analyzed. Some comment is included about those adoptive parents who were related to the candidate for adoption.

Standard Agency Procodure in Relationship to Adoptive Parents

The concerm of the child-placing agency with the adoptive parents who apply to them revolves around the readiness of the couple for a new relationship (the foundation on which rests the child's whole adjustment), the ability these prospective parents have shown in being ablo to discuss their proposod plans with their respective familles and mutual friends, as woll as their capacity for sharing, which is the root of their ablilty to adopt. 
The case-working agency proceeds on the assumption that, in applying, the would-be adoptive parents have asked to talk over this decision in the light of the reality of adoption. Those applicants who feel any child will do definitely need more help in exploring. What they expect from a child in his relationship with them, the level of the child's accomplishment as compared with their own and their ind vidual drives would be expected to come out during the making of a full and reasonably complete study of their home. All this is needed to weigh and balance with all that the child can bring to the adoptire home if it is to be considered for a particular child.

The caseworker needs to make a number of visits to the home in order to know the applicants as individuals. The social study must be a leisurely one, to give ample opportunity to the adoptive parents for the expression of their hopes, ambitions, satisfactions and dissatisfactions. It is through the social study that the applicants take an active part and accept some responsibility for the making of an adoption plan. Here again, they are enabled to feel and experience preparation for their prospective roles as adoptive parents. The prospect1ve parents appreciate the individual attention given them during this process of exploration, and therefore, with confidence, accept a plan made by the agency for a chlld to enter their home on a permanent besis, if they desire. The probation period is completed when they no longer feel there is any doubt, and having had the recommended one-year

1

Flizabeth Harral, "The Foster Parent and The Agency in the Adopt1on Process", Adoption Practice, (Cesework with Parent, Child and Foster Parents), (New York, N. Y.: Child Welfare Ieague of America, Dec. 1941), pp. 49-59. 
period explained to them early in the process of application, there 1s full acceptance of 1 ts purposes and meaning to them. At all times, they are free to return the child to the agency, whose first responsibility is to the child, the real client of the agency. It is in the child's interests, largely, that the entire process has been entered Into by the agency.

When the prospect1 vo adoptive parents (following the discussion of their desires for a child, with each other, and perhaps their frlends, the family physician and relatives on both sides) have brought themselves to the point of making an application for a child, the social worker sametimes appears as an obstacle for them to orercome in order to see a child and be presented with one. They are on the defensive when the worker visits in the home to see them in their own setting, and look upon her merely as an investigator in a role which involves some authority. An interpretation of what is meant by a trained chlld-plecing worker, would bring about a mare general and spontaneous acceptance of the functions of this worker. The more the social study made by the caseworker is seen as part of a procedure, preserving the interests and protection of the adoptive parents, the more quickly those desirous of obtaining a child will resort to the use of a child-placing agency, giving casework service.

It can be said that the caseworker in adoption should be familiar with a general body of knowledge pertaining to community life and the multiplicity of factors which are there intertwinod. The child-welfare worker noeds specific knowledge in the areas of behaviour, medicine, law, economics and other areas, and their relation to 
the making of a satisfactory adjustment by an individuel. This. specific knowledge is needed, not so much for direct use, but to help sharpen perception at that point where the specialist is noeded and sought. The knowledge of the mental hygiene and physical aspocts of the growth and derelopment of an indiridual is of help to the worker in recognizing any deviations of performance in an individual. Last, but certainly not least, the social worker must have an accepting, non-judgmental attitude toward other individuals, and the ability to recognize attitudes which have not been rerbalized by the individual. The worker must have experienced discipline, stresses and strains with subsequent success as a well adjusted person. Until her own problems are resolved satisfactorily, she cannot hope to play a responsible role in assisting others to an adequate adjustment in their life situations. All this is nocessary in order that she can be freo to focus her attention upon the neods of the adopted child, as related to the needs of the adoptive parents. At no time is the caseworker to set up herself as a superior personelity in the situation, but rather she is to malntain a plane of equality with the thinking and performance of the edoptive parents in this process of securing for them a child who is mutually recognized as the most suitable child obtainable, to become a permenent part of that family unit. The relation of the caseworker to her agency, its function and policies, froes her from the intimate personal aspects in the child-placing situation and thus with more ease she can discharge the responsibilities accompanyIng the decision of placing the candidate for adoption with the adoptive parents. 


\section{Relationship of Adoptive Parents}

Continuing our study of the adoptive parents, let us examine the relationship of these parents to the edopted children. The petitioners in twenty-two adoptions were relatives and in fifty-three they were other than relatives. These figures are shown in Table 13.

\section{TABLE 13}

STATUS OF CHITD AT BIRTH, BY RELATIONSHIP OF PEITIOANER TO CHIL

\begin{tabular}{c|c|c|c}
\hline \hline \multirow{2}{*}{$\begin{array}{c}\text { Status of Child } \\
\text { at Birth }\end{array}$} & & \multicolumn{2}{|c}{ Adopted By } \\
\cline { 2 - 4 } $\begin{array}{c}\text { Total } \\
\text { Total }\end{array}$ & Relatives & $\begin{array}{c}\text { Other than } \\
\text { Relatives }\end{array}$ \\
\hline Born In Wedlock & 75 & 22 & 53 \\
Borm Out of Wedlock & 27 & 15 & 12 \\
\hline
\end{tabular}

The relatives who were petitioners included fourteen stepfathers, no stepmothers, two grandparents (on the maternal side) and six who were other relatives, five of whom were in the relationship of cousins and one an uncle to the adopted child. Seventy per cent of the adoptions were by adoptive parents who were other then relatives. This is shown in Table 14. 
TABLR 14

RRELATIONSEIP OF

ADOPTIVE PARENTS TO CHILD

\begin{tabular}{l|c|c}
\hline \multicolumn{1}{c|}{ Relationship } & Number & Per Cent \\
\hline Total & 75 & 100.0 \\
\hline Relatives & & \\
Steprather & 14 & 18.6 \\
Stepmother & 0 & 0.0 \\
Grandparents & 2 & 2.7 \\
Other Relatives & 6 & 8.0 \\
Other than Relatives & 53 & 70.7 \\
\hline
\end{tabular}

Security

Although we think it is equeliy important to examine the 1

motives for adoption by relatives, we are more concerned with those of the adoptive parents where there were no blood-ties of relationship because of the great responsibility involved in these placements in an effort to assure future security for the child.

Lot us examine security. A sociel psychologist, Mr. W. I. Thomas discusses the desire for security as the second of four categorles into which he classified the simple human wishes of all individuals. The four categories are: (I) the desire for new expertence; (2) the desire for security; (3) the desire for response; and (4) the 2 desire for recognition. If these wishes are in balance, we may

${ }^{1}$ Lucie K. Browning, "A Private Agency Looks at the End Results of Adoptions". Child Welfare League of Americe Bulletin, Vol. XXI, No. 1 , Jan. 1942, p. 3 .

2

Healy, Bronner, Bayl or \& Murphy, Reconstructing Behavi or in Youth (New York, N. Y.: Alfred A. Knopf, 1931), p. 143. 
expect the emergence of an integrated personality.

The trained chlld-placing worker in the field of adoption takes into account the opportunities offered in the adoptive home for the candidate for adoption to have a balanced opportunity for the fulfillment of these four fundamental wishes. It is here that we cannot know too much about the adoptive couple and their respective personalty traits, ambitions, capacities to share in giving recognition to others, and the capacity for consistent behaviour to create an acceptable pattern, as related to the mores of that community in which the adoptive parents live. The soclal worker, having been helped by technical training, appreciates the great variety of acceptable patterns of behaviour, without any preference or feeling of alsapproval for the level of achievement into which the adgptive family has arrived.

We are assuming, broady, that there is no social caste in a democracy. In other words, that a femily limited in formal education, economic resources and appreciation for great achievement is st111 capable of providing a setting for a candidate for adoption of relatire ability. For the happiness and security of each candidate for adoption, the most important thing is to place each child in thet enviroment which is most easily related to his innate capacities. Therefore, we cannot devel op too much akill to work effectively in the matching process of adoptive parents to the candidate for adoption.

Age of Adopt Ivo Parents

The age of natural parents of a young child is normally between twenty and thirty, and it is oasily understood that adoptive 
parents might be from thirty to forty, because the decision to adopt a child is usually deferred untl 1 it is relatively certain that the foster parents will heve no children of their own. Since the purpose of adoption is to give a child a home, as nearly as possible, approximatIng a natural family home, it is questionable whether adoptive parents would be able to particlpate satisfactorily in the parent-chlld relationship, if the adoptive parents are more than ten years older then that of the natural parents. Therefore, the twelve "other persong", who were forty or over, adopting children are subject to question. The age of the adoptive mother was used as an index because it is she who more ofton is in closest relationship to the adopted child. The ages of the adoptive parents appear below in Table 15.

\section{TABLE 15}

AGE OF ADOPTIVE MOTHER, BY RKKATIONSEIP TO THE ADOPTIED CHIDD

\begin{tabular}{|c|c|c|c|c|c|}
\hline \multirow{3}{*}{$\begin{array}{c}\text { Age of } \\
\text { Adoptive Mother }\end{array}$} & \multicolumn{5}{|c|}{ Ch1ldren who were Adopted } \\
\hline & \multirow[b]{2}{*}{ Total } & \multicolumn{3}{|c|}{ By Relatives } & \multirow[b]{2}{*}{$\begin{array}{l}\text { By Other } \\
\text { Persons }\end{array}$} \\
\hline & & $\begin{array}{c}\text { Own or } \\
\text { Stepparents }\end{array}$ & $\begin{array}{l}\text { Grand- } \\
\text { parents }\end{array}$ & $\begin{array}{c}\text { Other } \\
\text { Relatives }\end{array}$ & \\
\hline Total & 75 & 14 & 2 & 6 & 53 \\
\hline Under $30 \mathrm{yrs}$. & 24 & 7 & 0 & 1 & 16 \\
\hline 30 yrs., under 40 & 34 & 6 & 0 & 3 & 25 \\
\hline 40 yrs., under 50 & 8 & 1 & 0 & 1 & 6 \\
\hline 50 grs., under 60 & $\eta$ & 0 & 0 & 1 & 6 \\
\hline 60 yrs. and over & 2 & 0 & 2 & 0 & 0 \\
\hline
\end{tabular}


of these twelve, six of the adopted children were six years of age or younger. Four of the adoptive mothers bad been boarding mothers first, and through this relationship had become attached to the child. One of the children was of "low averagen Intelligence, and the boarding parents felt that they understood her slow responses better than anyone else would. They had successful older children who approved this child's becoming a member of the family. The casework implications were that little would be demanded of the child. There had been demongtrated an accepting environment, in which orery advantage would be given her to develop with adequate satisfactions. The child had been observed and studied over a period of several years, and she had been in this home since her removal at the age of three wooks from a maternity home. The mother had not wanted to know her address; therefore, the mother would offer no problem by reontering the situation at a later date to threaten the security of the adoptive parents or the child.

One chlld was colored. In this case, the boarding parents had boarded the child for two and one-half years.

\section{Foster Study Homes}

Foster boarding homes are investigated, epproved and licensed before a child is placed in them. They offer opportunity for the

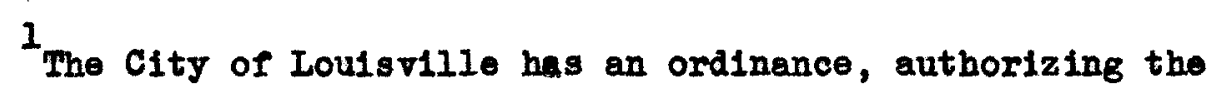
Child Housing Division to Investigate and issue ilcense to those boarding homes where there is no relative of the child living in the home. This does not apply to homes outside the city limits. 
study and development of the candidate for adoption. Four, as rovealed In our study, seems a small number of boarding parents to have become attached to the children, to the point of desiring to adopt the boarded child, who was being prepared by them, under agency supervision, for plecement in an adoptive home. Affectional ties are needed to nurture and adequately encourage the child's fullest progress in development, and boarding mothers are in a situation where affectional ties are nurtured and expanded.

The motive of boarding mothers is usually the desire to have a child in the home, often after the "own children" have become adults, married, or left the city. A part of the foster home investigation is to ascertain that there is no economic need, because it is recognized that the usual boarding home rate, paid by child-caring agencies; bardy provides more than the cost of the child's food.

\section{Education}

The educational attainment of a person may have little relation to his desirability as an adoptive parent, but ordinarily it affords an indication of $\mathrm{hls}$ interests, as well as what might be expected intellectually of a child in his home. The educational background of the foster parents should be taken into consideration, because the child's happiness is to some extent dependent on his ability to meet the intellectual expectations of his foster parents and to accept the opportunities they offer him. 
There are many parents who have had grade school education only, and have subsequently carred out an economically and emotionally secure existence. If they desire more education than they had for the ir children, it is important to explore the attitudes of the adoptive parents, should the child be unable to accept higher education. Visualize the discanfort caused to a superior child placed in an adoptive home where there is no appreciation of, or encouragement to, him for endeavor on a higher level.

Not enough children had been given psychological examinations to warrant making a comparison between the child's innate ability and the parents' educational attainment. This was one of the weak points in the adoption picture and we think one of the most vital, in order to aroid the over-placement or the under-placement of the candidate for adoption.

With the six adoptive parents having a college background, The Children's Agency placed two children, each of "superior" intelligence, and The Home of the Innocents, one ch1ld with "high average" intelligence, while the other children placed in the adoptive homes with college background apparently were not tested. An old placement made eleven years ago by the Kontucky Children's Home, prior to its use of the staff psychologist of the Child Welfare Division, showed the child was doing "just average" work in school. The adoptive father had planned a college and professional career for this child. We recognize that this could have happened in the case of a natural child. But all parents who seek a child have lost the child of their dreams and at best the adopted child is a substitute. It is necessary 
to recognize that every such family is a deprived family, to some extent, a neurotic family. As individuals they may be adequate but as 1

a couple they have falled. We are not wholly in accord with this description of a childress couple but it is something to take into consideration, if parents lack flexibility in their existing attitudes. One child was placed by Our Lady's Home for Infonts. The natural mother had completed three years of high school. Her occupation was in the amall wage group of restaurant workers.

The sixth child in a home with college trained adoptive parents was placed through the femily physician. The natural mother was said to have completed high school, but this could not be verified.

In respect to their goals for the education of the adopted child, it is well for the caseworker to look for flexibility in planning upon the part of the adoptive parents to assure acceptance of the performance of that child.

The formal education of adoptive parents appears in Table 16.

Other Persons in the Adoptive Homes

The majority of adopting parents were childaless for in 80 per cont of the serenty-fire there ras no one in addition to the adopting parents in the home. This reliered the adopted child from competition with another child for love and affection. Certainly it is easier for the adopted child to grow comfortably into his status in the home if

${ }^{I}$ Dr. Leslie E. Luehrs, Consultant Psychiatrist to State Charities Ald Placement Lept., New York, The Worker's Role in Adoption, Adoption Practice (Case Nork with Parents, Child and Foster Parents) (New York, N. Y.: Child Nelfare League of America, Dec. 1941), p. 7. 
TABLE 16

HXXTENT OF FORAAL EDUCATION

OF ADOPTIVE PARTNIS, *

BY RELATIONSHIP OF

THE PAREINIS TO THE ADOPTED CHIID

\begin{tabular}{|c|c|c|c|}
\hline \multirow{2}{*}{$\begin{array}{c}\text { Extent of } \\
\text { Formal Education } \\
\text { of Adoptive Parents* }\end{array}$} & \multicolumn{3}{|c|}{ Children who were Adopted } \\
\hline & Total & $\begin{array}{c}\text { By } \\
\text { Relatives }\end{array}$ & $\begin{array}{l}\text { By Other } \\
\text { Persons }\end{array}$ \\
\hline Total & 75 & 22 & 53 \\
\hline College Graduation & 6 & 4 & 2 \\
\hline Some College & 4 & 0 & 4 \\
\hline High School Graduation & 23 & 5 & 18 \\
\hline Some High School & 13 & 5 & 8 \\
\hline Eighth Grade & 26 & 7 & 19 \\
\hline Sixth or Serenth Grade & 3 & 1 & 2 \\
\hline Iess than Sixth Grade & 0 & 0 & 0 \\
\hline
\end{tabular}

*

Parent having the higher degree of formal education

there is no competition or sibling rivalxy to combat. Only one adoption by "other persons" had the adopt1re maternal grandparents in the home. In four of these adoptions by other than relatives there were own children who were much older by comparison with the adopted child. All the children were observed, and all seemed as if they were natural children. 
TABLE 17

NUMBER OF PERSONS

IN THE ADOPIIVE TAMTIY,

BY RHLATIONSHIP OF

CHIID TO ADOPTIVE PARENTS

\begin{tabular}{|c|c|c|c|c|c|}
\hline \multirow[b]{3}{*}{$\begin{array}{l}\text { Number of } \\
\text { Persons in the } \\
\text { Adoptive Family }\end{array}$} & \multicolumn{5}{|c|}{ Number of Children Adopted } \\
\hline & \multirow[b]{2}{*}{ Total } & \multicolumn{3}{|c|}{ By Relatives } & \multirow[b]{2}{*}{$\begin{array}{l}\text { By Other } \\
\text { Porsons }\end{array}$} \\
\hline & & $\begin{array}{c}\text { Own or } \\
\text { Stepparents }\end{array}$ & $\begin{array}{l}\text { Grand- } \\
\text { parents }\end{array}$ & $\begin{array}{c}\text { Other } \\
\text { Relatives }\end{array}$ & \\
\hline Total & 75 & 14 & 2 & 6 & 53 \\
\hline 1 Porson & 1 & 0 & 0 & 0 & 1 \\
\hline 2 Perscons & 60 & 12 & 1 & 5 & 42 \\
\hline 3 Persons & 4 & 0 & 0 & 1 & 3 \\
\hline 4 Persons & $\eta$ & 2 & 0 & 0 & 5 \\
\hline More than 4 Persons & 3 & 0 & 1 & 0 & 2 \\
\hline
\end{tabular}

Income

With the exception of eleven adopt1ve homes, the annual income was reported. For those eleven, seven incomes were described as "Adequate" and three as "Better than Adequate". Throe adoptive mothers were employed, one in the higher income bracket at $\$ 5,000,00$ or more (including the adoptive father's incane) and two were in the lower income brecket of $\$ 1,000.00$ to $\$ 2,000.00$. During the process of the adoption investigation, one mother discontinued her employment in order to spend more time with the child. Apparently this wes due to mutual exploration with the caseworker of the parent-child relation- 
ship, and the need for the adoptive mother to be in the home.

Fifty-nine per cent of the relatives' homes fell in the income bracket under $\$ 3,000,00$ per annum, while 64 per cent of the annual incomes of other than relatives fell in that same income group. For Incomes over $\$ 3,000.00$ per annum there was a total of 36 per cent in the relatives' homes. In comparison, only 16 per cent of the other then relatives' incomes fell in the bracket of $\$ 3,000.00$ or over. However, this might have been due to the absence of a report of income for ten. of the four relatives with income over $\$ 5,000.00$, two were given as $\$ 10,000.00$ and $\$ 15,000,00$ per annum. The distribution of annual incomo 18 given below.

\section{TABLE 18}

ANNUAC INCONE IN ADOPTIVI HOMES

\begin{tabular}{c|c|c}
\hline & $\begin{array}{c}\text { Relatives' } \\
\text { Homes }\end{array}$ & $\begin{array}{c}\text { Other Porsons' } \\
\text { Homes }\end{array}$ \\
\hline Total & 22 & 53 \\
\hline Less than $\$ 1,000$ & 0 & 0 \\
$\$ 1,000$, Less then $\$ 2,000$ & 8 & 22 \\
2,000, Less than 3,000 & 5 & 13 \\
3,000, Less than 5,000 & 4 & 7 \\
5,000 or More & 4 & 10 \\
Not Given & 1 & \\
\hline
\end{tabular}




\section{Motives for Adoption}

The court reports revealed the largest number, thirty-six or 46 per cent, of the adoption cases as having physical reasons precluding pregnency as the desire for children on the part of those unable physically to bear children. The second largest number, thirteen or 17 per cent, of the adoptive parents gave the legal right to use stepfather's name as the motive. One child in this group was ready to enter school.

Four adoptive parents had boarded the child and had become attached to the child. Five adoptive parents wishod to guard the inheritance rights of the child. In five cases, motives were not given. There were ten whose motives seemed to need individual classification. One hed two boys and wanted a girl. One couple "could not afford children" and took a deceased relativo's child with an inborited personal income. In still another situation, the matermal grandparents stated they wanted to "roar own flesh and blood". In another adoption, the relatives were interested only in that child, otherwise they would never have thought of adoption. One stepfather wanted to remove the atigma of the name of a criminal father. In the only situation in the entire study where there was no living adoptire father, the adoptive mother wanted the young girl to have the privilege of legelly using the adoptive father's name, by which she was custcmarily known. For three adoptive parents, an "own child" had diod and the adopted child was to be considered in the plece of their own child. The adoptIre parents' motives for adoption appear in Tablo 19. 
TABLE 19

THE ADOPTIVE PARERTIS'

MOTIVRS FOR ADOPTION

\begin{tabular}{l|c}
\hline \multicolumn{1}{c|}{ Total } & 75 \\
\hline Physical Reasons Procluding Pregnancy & 35 \\
Boarded and Became Attached & 4 \\
To Sareguard Inheritance Rights & 5 \\
Requested by the Candidate for Adoption & 3 \\
Logel Right to Use Stepfather's Name & 13 \\
Other & 10 \\
Not Given & 5 \\
\hline
\end{tabular}

Duration of Married Life

In a measure, the number of years of married life prior to making an adoption plan might be considered an index of hor long the adoptive parents had waited before deciding to conform to the conventional family pattern. The largest number, twenty-three, or 30 per cent of the adoptive parents, had been married ten years or orer. The smallest percentage was 18 per cent, for fourteen cases, married less than three years. Sixty-zeven per cent of the adoptive parents were married less than ten years. 
TABLE 20

DURATION OT MARRTKD ITITE

PRIOR TO CHIID-PLACIMMENT

IN ADOPIIVE HONC:

\begin{tabular}{c|c|c}
\hline \multicolumn{1}{c|}{ Period } & $\begin{array}{c}\text { Number of } \\
\text { Adoptive } \\
\text { Parents }\end{array}$ & Por Cont \\
\hline Total & 75 & 100.0 \\
\hline Ioss than $3 \mathrm{yrs.}$ & 14 & 18.4 \\
$3 \mathrm{grs}$. to Less then $5 \mathrm{grs}$. & 15 & 19.7 \\
$5 \mathrm{grs}$. to Less than $10 \mathrm{grs}$. & 21 & 29.0 \\
$10 \mathrm{grs}$. and Orer & 23 & 30.3 \\
Not Given & 2 & 2.6 \\
\hline
\end{tabular}

It is not doubted that the adoptive parents heve had generous impulses to enter into an adoptive relationship with a child. That is not enough. Their job is doubly difficult because they are not the natural parents. To share the burden of a heredity for which they are not responsible, and to do 80 in the intimacy of their home, is an undertaking demanding infinite patience and ingenuity, and constant adjustment to unpredictable conditions. Adoption cannot be a selfish gratification; it must not hope for reward; it cannot count on success. The reports revealed adoptive parents of diversified cultural levels, and for each couple we hope there was a child to derlve adequate satisfactions in a socially acceptable fashion.

After haring completed this study of the three parts of the 
adoption process, namely, the natural parents, the child, and the adoptive parents, our message for the public is: there is still much to be done in the field of adoption; let the public be less complacent and ignorently optimistic; let them be inspired to gain a wider knowledge of the delicate issues involved; and let there be a further swing away from romanticism to realism.

This chapter has been an attempt to describe the agency procedure in the investigation of the suitability of the adoptive home, to interpret the dynamios of the agency relationship with the adoptive parents, and to give a definition of security in the light of the ability of the adoptive parents to give the child a feeling of belong1ng. From the reports, an analysis of the factors which enter into the matching process of the child with the adoptive parenti, namely, the age, formal education, economic status, duration of married life, other members of the adoptive family, and the motives for adoption, is given. Comment on adoptive parents who were related to the child has been included.

Under each speciflc topic we have pointed out the adverse aspects of the adoptive placement but because each situation at the point of adoption seemed to the best interests to preserve the child's security, all of these adoptlons studied had been approved. Certainly the edoptive home to all appearances offered more than did the naturel home, but in some instances better adoptive homes could well have been given those children capable of responding satisfactorily on higher levels of adoptability.

${ }^{1}$ Carol s. Prent1ce, An Adopted Child Looks at Adoption, New York: D. Appleton - Century, 1940, p. 213. 
concrusian 


\section{COATCLUSION}

This examination of the operation of the Kentucky law of 1940, as revealed in these serenty-fire cases, indicates:

(1) that the Kentucky law is in line with progressive logislation on adoption;

(2) that its administration admits of improvoment in the following respects:

a. In regard to natural parents, there were only eleven cases in which both the consent of the naturel parent or parents and legal camitment to the agency or institution were obtained.

- b. Iegal paternity was established on only two of the forty-eight children of unwed mothers. As long as inheritance rights are part of the present adoption law, it would be well to encourage the establisment of paternity to preserve the inheritance rights of the child with respect to the natural parents. Paternity establishment contributes to the future motional security of the child.

c. In regard to the candidate for adoption, the physical condition of the child should be rerified and the making of renereal tests required. It is possible that renereal tests had been made and the information was onitted in the court report.

d. Psychological tests should be made on every candidate for adoption if the description of the mentel status is to be a valid one. Only fifteen children were given psychological examinations. By the cmission of this modern contribution of psycholost, the untested 
children and the adoptive parents did not recelve the protection to which they were entitled. Only twelve of the forty-eight unwed mothers had been giren psychological tests. Therefore, the hereditary contribution of the untested mothers was unimown.

- On the basis of this otudy, there is a real need for. onabling legislation to improve and control the adoption procedure at an earlier period than at the time when the adoption petition is illed and the required social investigation is begun. Onder the present law, It was through no fault of the Child Welfare Division or its delegated representative which made the social investigations that there was inadequate history of the natural parent. This history was not collected prior to the date of the placement of the child. An earlier entrance into the situstion would facllitate the collecting of adequate social history vitally noeded in making a fitting placement of the child. This would prevent casual adoptive placements of children by persons untrained in the field of adoption. This study revealed two infants were placed by the attending physician.

I. In Iffty-five of the adoptions, the now birth certificate had been secured. Apparently some of the children had been borm in states not jet proriding for the new birth certificate.

From the findings in this study, the general conclusion is that the adninistration of the adoption law is as effective as it can be within its linitations. The new law does not encompass fully the social aspects of adoption or adequately safeguard those placements made by independent persons or institutions not alert to, or aware of, the progressive technlques of good adoption prectice. 
The study showed that the Child Welfare Dirision, in its Investigatorial role, is making atrong efforts to interpret the speclalized techniques of good adoption practice and, in time, with greater cooperation from those engaged in child-placing, more specific improvement can be expected in the adoptions of the future in Jefferson County and throughout the state of Kentucky.

A general improvement would be brought about in tho administration of the adoption law if the following reccmmendations could be effected:

(1) that the Child Welfare Division, with the participation of all agencies or institutions engaged in child-placing for adoption, work out a set of Standards of Adoption Practice, to be approved by the central authority, the Chlld Welfare Division, for use in IicensIng those agencies or institutions;

(2) that all agencies or institutions be required, by statute, to qualify under the accepted standards of Adoption Practice;

(3) that the period of social investigation be more le1surely one, and be extended to ninety days, instead of the present sixty days, in order to give a more effective service to the child and the adoptive parents;

(4) that the present law be amended so that all parents would have to be referred to the Ohild Felfare Division, of the State Department of Welfare, or its delegated representative, which should be an approved agency or institution, at the time when there is an expressed desire to place the child for adoption;

(5) that the birth certificate be secured as a part of the 
adoption service to be discharged before the agency or institution which placed the child withdraws from the situation;

(6) that all institutions doing adoption secure a consent to adoption and legal commitment of the candidate for adoption as a protection to the adoptive parents and the child;

(7) that the probation or adjustment period be extended to one year, and that adoptive placements of children under aix months of age be discouraged. Authorities suggest it is preferable to place no child under nine months of age;

(8) that those in charge of child-placing be assisted to real1ze the Importance of a child's learning at an early age that he is adopted, in order that emotional maladjustments at a later date may be aroided. This is a current polley of the Ohild Welfare Division and routinely advised as a part of the casework service given during the period of social investigation. 
BIBLIOGRAPHY 


\section{BIBLIOGRAPEY}

\section{Books}

American Juxisprudence. "Adopt 1on". lst ed. Vol. 1. Rocbester, I. Y., 1936. Pp. 619-677.

Brooks, Lee M., and Brooks, Frelyn C. Adventuring in Adoption. Chapel Hill, N. C.: University of North Carolina Press, 1939. P. 225 .

Cellagher, Fleanor. The Adopted Ch1ld. New York: Reynal and Hitchcock, by John Day Publishing Co., 1936.

Hoaly, Bronner, Baylor and Nurphy. Reconstructing Beharlour in Youth. New York: Alfred A. Knope, 1931.

Knox, Sarah T. The Fanily and The Iar. Chapel H11l, N. C.: Unitersity of North Carolina Press, 1941. Pp. 97-110.

Pennayltania School of Social Work. Social Case Work with Children.

Vol. III. Journal of Social Work Process, Philadelphia:

Centaur Press, 1940.

"Adoption as the Commanity Sees It". Mary Frances Smith. Pp. 6-28.

"Helping the Very Young Child to Participate in Placement". Marian Gennaria. Pp. 29-59.

Pennsylvania School of Social Work. Function and Process. Vol. I. Journal of Soctal Work Process. Philadelphia: Contaur Press, Nov. 1937.

"The Temporary Home as an Integral Part of Adoption

Procedure". Mary N. Taylor. Pp. 67-84.

"Runction in Child Placement". Helen Baum.

Prentice, Carol. The Adopted Child Looks on Adoption. New Yorik:

D. Appleton - Century, 1940.

Slingerland, W. H., A. M., D. D. Child Placing in Families. New York: Russell Sage Foundation, 1918.

Thom, Douglas A. Normal Youth and Its Everyday Problems. New York, 2932.

Walker, Wilma. Child Welfare Case Records. Chicago: University of Chi cago Press, May 1937. 
Periodicals, Pamphlets, Bulletins

Bishop, Julia Ann. "The Child's Part in Adoption Placement". Adoption Practice (Case Work with Parent, Child and Foster Parents). New York: Child Velfare League of Amer1ca, Dec. 1941.

Bourne, Margaret C. "A Ploneer Job in Court Adoptions". Child Welfare League of America Bulletin, May 1940.

- "The Wish is Father to the Need". Child Welfare League Bulletin. Vol. XVIII, No. 2, Fob. 1939. P. 5 .

Brenner, Ruth. "Casework Service for Unmarried Mothers". The Family. Albany, N. Y., Nov, and Dec. 1941.

Brooks, Lee. "Forty Foster Homes Look at Adoption". The Fam1ly, Mar. 1934.

Browning, Lucie K. "A Private Agency Looks at the Fnd Results of Adoptions". Child Velfare League of America Bulletin.

Vol. XXI, No. 1, Jan. 1942 .

Clothier, Florence, M. D. "Sone Aspects of the Problem of Adoption". American Journal of Orthopgychlatry. Vol. IX, No. 3, Pp. 598-615.

- "Problems in the Placement of Illegitinate Children". Child Wolfare League Bulletin. Vol. XX, No. 3, Mar. 1941. Pp. 1, 2, 3 and 8 .

- "The Social Worker in the Field of Adoption". Montal

Hygiene. Vol. XXIV, No. 2, Apr. 1940. Pp. 210-215.

"Adoption Procedure in the Cammunity". Mental Hyglene.

Vol. XXV, No. 2, Apr. 1941. P. 197.

- "Problems of Illegitimacy as They Concern the Worker in the Field of Adoption". Mental Hypiene. Vol. XXV, No. 8, Oct. 1941. P. 576.

Colby, Mary Ruth, Modern Safeguards in Adoption Legislation". Child Welfare League Bulletin. Vol. XX, No. 10, Dec. 1941. Pp. 3, 4, 5 and 6 .

- "Problems and Procedures in Adoption". United States Children's Bureau Publication. No. 262. Washington, D. C., 1941.

- "Progress in Adoption Legislation". The Social Service Revien. Vol. XVI, No. 1, Mar. 1942. 
"Protection of Children in Adoption". Proceedings of National Conference of Social Work, 1938. Pp. 146-161.

Connolly, Vera. "Bargain Counter Babies". Plctorial Review, Sept. 1937 (Out of Print). P. 17.

Cowan, Edwina, Ph. D. "Some Emotional Problems Besetting the Lives of Foster Children". Mental Hygiene. Vol. XXII, July 1938. P. 454.

Gardner, Mona. "Traffic in Babies". Collierg, Sept. 1939. P. 14.

Gillean, Susan. mThe Responsibility of Private Child Welfare Agencies for Adoptions". Child Welfare League Bulletin. Vol. XVIII, No. 6, June 1938. Pp. 1, 2, 4 and 5.

Goldfarb, Wm., Ph. D. "A Psychologiat's Services in a Child Placing Agency". The Family. New York, June 1941.

Hallowell, Dorothy Kern. "Validity of Tests for Young Children". The Pedagogicel Seminary and Journal of Genetic Psychology. (Quarterly), June 1941. Provincetown, Mass.: The Journal Press, No. 2. Pp. 268-288.

Hanna, Agnes K. "Special Certificates for Adopted Children". The Child. J. S. Children's Bureau, May 1942.

Harvey, Holman. "Out of Wedlock". The American, Oct. 1939.

Heisterman, Carl A. "A Sumary of Leglslation on Adopti on". Social Service Review. Vol. IX, No. 2, June 1935.

Harral, Elizabeth. "The Foster Parent and The Agency in the Adoption Process". Proceedings of the National Conference of Soclal Work. New York: Columbia University Press, 1941. Pp. 411-425; also Adoption Practice, Child Welfare League of America, Dec. 1941.

Holliday, P. O. Judge. "A Judge Considers Adoption". Child Welfare League Bulletin. Vol. Xx, No. 10, Mar. 1938. $\frac{\text { Pp. 1, 2,6 and }}{7 .}$

Jenkins, R. I., M. D. "Adoption Practices and the Physician", Joumal of American Medical Association, Aug. 1934.

Jones, Nlizabeth. "The Administration of the Adoption Law in Cook County, Illinols". Social Service Revier. Vol. XI, No. 4, Lec. 1937. Pp. 665-692.

Knight, Robert P., M. D. "Some Problems Involved in Selecting and Rearing Adopted Children". The Bulletin of Menninger Clinic. Vol. V, No. 3. Topeka, Kan., May 1941 
Lawson, Douglas E., Ph. L. "Adopting a child". Hygeia, Sept. 1942. P. 668 .

- "Social and Legal Problens of Adoption". Hygela, Nor. 1942. P. 830 .

Luehrs, Leslie E., M. D. "The Worker's Role in Adoption". Adoption Pract lce, (Casework with Parent, Child and Foster Farents). Child Welfare League of America. New York, Dec. 1941.

McKinley, G. M., M. D. "Genetics in Child Adopt 1on". Child Welfare League Bulletin. Vol. XTX, No. 3, Mar. 1940. Pp. 3, 7 and 8.

Pendleton, Ora. "Agency Responsibility in Adoption". The Fam1ly, Apr. 1938.

- "A Decade of Experience in Adoption". Annals of the American Academy of Political and Social Science. Children in a Depression Decade. Vol. 212, Nov. 1940. Pp. 186-193.

Philbrick, Norna. "The Problem in Knowing Adoption Babies". Proceedings of National Conference of Social Work, June $1 \overline{939}$.

Puschner, Hma. "Child Adoption - Our Most Difficult Undertaking". Child Welfare League of America Bulletin. Vol. XVI, No. 6, June 1937. Pp. 2, 4 and 5 .

Symmes, rdith F. "An Infant-Testing Service as an Integral Part of the Child-Guidance Clinic". American Journal of Orthopaychiatry. Vol. III, No. 4, 0ct. 1933. Pp. 409-430.

Thom, Douglas A., M. D. "Adoptions". Journal of Pediatrics. Vol. IV, No. 2, Aur. 1939.

Statistical Survey (Quarterly). "Study of Adoption in Four Indiana Counties". Department of Public Welfare: Indianapolis, Ind., Apr., May, June 1941.

Taft, Jessie, Ph. D. "The Need for Psychologlcal Interpretation in the Placement of Dependent Children". Bulletin No. 6. Child Welfare League of America, Apr. 1922.

Van S. Theis, Sophie. "Some Aspects of Good Adoptive Practices". Child Welfare League of America Bulletin. Vol. XIX, No. 9, Nov. 1940. Pp. 1, 2 and 3 .

"Adoption". United States Children's Bureau. Folder 13, 1938.

"The A B C of Foster Family Care for Children". United States Children's Bureau. No. 216. 
"Doctors and Infant Adoptions". Northwest Modicine. Vol. 20001 , No. 11, Nor. 1933.

"Suitability of the Child for Adoption". Americen Journal of

Orthopsychiatry. Vol. VII, No. 2, Apr. 1937. Pp. 270-273.

\section{Reports}

White House Conference. "Child Health and Protection". Dependent and Neglected Children. D. Appleton - Century Co., 1933. P. 267.

Public Documents

Statistical Abstract of the United States. United States Goverment Bulletin. Washington, 1940.

Onited States Bureau of the Census. Sixteenth Census of the United States: 1940. Population. Table 22. Washington: Goverment Printing office, 1941.

\section{Legal Statutes}

Oregon Code. Sec. 31-716, 1933.

Carroll's Kentucky Statutes. Baldwin's Annotated. 1936 and 1940 Editions.

Unpublished Material

Clarke, Eric Kent. "Revolt Against Circumstance". Unpublished Doctor's D1ssertation. University of Rochester (Department of Psychiatry), Rochester, N. Y., 1938. 
APPIADIX I 


\section{ADOPTION IAYI}

Sec. 33Ib-3. Persons who may adopt or be adopted; parties.

(1) Any adult person who is a resident of Kentucky may pet1tion the county court of the county of his legal domicile for leave to adopt a child or another adult. No petition by a married person shall be grented unless the husband or wife joins therein, excepting that when the petitioner is married to the natural father or mother of the child joinder by the father or mother is unnecessary.

(2) Any person may be adopted after arriving at the age of twenty-one years as well as chlldren before reaching that age.

(3) No petition for the adoption of any minor child shall be granted until the child has lived for a period of three months in the home of the petitioner.

(4) The child to be adopted together with its natural living parents, if born in wedlock, but if not, then its mother, if Iiving and any testamentary or statutory guardien it may have, shall be made parties defendant to said orlginal petition for adoption. If said child has no living parents and no guardian, then the person or persons standing in $10 c 0$ parentis thereto shall be made parties defendant therein, or if the care, custody and control of said child has been lawfully transferred to any cheritable institution or association by a court order, then such charitable institution or association shall be deemed as standing in loco parentis and sholl bo a party defendent. In such instence the natural parents if child born in wedlock or the 
mother of such child if born out of wedlock shall not be necessary partios to any such action, but in the absence of any of the above named, the Department of Welfare, or its authorized agent, shall be made a party defendant with said child. Fach defendant thereto shell be brought before the court by personel or constructive service in the same way and manner as is provided for in the Civil code of Prectice in other clifil actions.

Sec. 331b-4. Proceedings for adoption; investigation; hoaring.

(1) Opon the filing of a petition for the adoption.of any minor child the court shell cause an investigation to be made of the former environment and antecedents of the child for the purpose of ascertaining whether he is a proper subject for adoption and of the home of the petitioner to determine whether it is a suitable home for the child. The investigation shall be made by the State Department of Welfare, or by any agency which the State Department of Welfare may authorize to conduct the investigation. The results of the investigation shall be embodied in a full report in writing, which shall bo submitted to the court at or prior to the hearing upon the petition and be filed with the records of the procesdings and become a part thereof. The report shall contain a full statement of facts found in the Investigation and a recomendation as to the desirability of the adoption.

(2) Opon the filing of a petition for adoption the court shall appoint a time and place for hearing which shall allow reasonable time of not less than sixty days for the prior investigation provided for in this section. The court shall mail notice of the date of 
hearing to the State Department of Welfare. The petitioner and the child to be adopted, if fourteen years or orer, shall be required to attend the hearing in person, but a younger child shall not be required to attend unless the court so orders.

Sec. 33Ib-5. Consent of parties.

Except as otherwise specified in this section no adoptions shall be permitted except with the notarized consent of the living parent or parente of the child or the mother of a child born out of wedlock or if parents cannot be located after reasonable search, next of kin, guardian or person standing in 1000 parentis.

(1) In the case of a child fourteen years of age or over the consent of the child must be given in writing in the presence of the court.

(2) Consent shall not be required of the parents of a child when the rights of such parents have been terminated by order of a court of competent jurisdiction; provided, however, that in such cese adoption shall be permitted only on the consent of the State Department of Welfare, after a full investigation has been made by it, or some agency designated by it to make such investigation.

(3) If such child has no living parent adoption shall be permitted on the consent of the legal guardian of the child, or if the re be no guardian by person standing in loco parentis, or if child is destitute of kin or guardian, by the State Department of Welfare, or by an agency or institution approved by 1 it.

(4) In the case of a child, not born in lawful wedlock, consent of the father shall not be necessary, but in such cese adoption 
shall not be permitted without the consent of the State Department of Welfare, or some agency designated by it to give such consent, after a full investigation of the case has been made by the State Department of Welfare, or of scme agency designated by it to make such investigation.

(5) In case the person to be adopted has arrived at the age of twenty-one years the consent of such person alone shall be necessary .

(6) In the case where the consent of a minor parent is required a guardian ad litem therefor shall be required and the consent of such minor parent shall be effective only if concurred in by the guardian ad litem.

Sec. 331b-6. Order of adopt 1on; adopting persons, child; contents of order; nome of child.

(1) The court shall not render an order of adoption of a ninor child unless the court is satisfied that the petitioners are of good moral character, of reputable standing in the community and of ablilty properly to maintain and educate the child, that the best interests of the child would be promoted by adoption, and that the child is suitable for adoption.

(2) If after the hearing and recelving the required consent of the person whose consent to adoption is necessary the court is aatlafied that the facts stated in the petition are true and that all legal requirements relating to adoption have been complied with, the court shall render an order setting forth all the juriadictional facts and providing that from and after date thereof the child shall be 
deemed to all legal intents and purposes the child of the petitioners. In the order the name of the child may be changed to that of the parents by adopt1on.

Sec. 33Ib-7. Keport after adoption order; records br state health board.

After entry of such order the clerk of the court shall promptly report to the State Board of Health, Bureau of Vital Statistics, full information as to: (I) the prior name of the child, (2) the date and place of b1rth of the child, (3) the name of the naturel parents of the child, (4) the name and address and occupation of the parents by adoption, (5) the new name of the child, if any, (6) and the date of the order of adoption of the court issuing the same. Upon recelpt of the order of adoption the state Board of Health, Bureau of Vital Statistics, shall cause to be made a new record of the birth in the new name, and it shall then cause to be filed the original certificate of birth together with a new certificate which shall set forth the facts above.

Sec. 331b-8. Inheritance by and Irom adopted child; support of natural parents regulated.

The child so adopted shall be deemed for purposes of inheritance and succession and for all other legal consequences and inc1dents of the natural relation of parents and children, the same to all Intents and purposes as a child borm in lawful wedlock of such parents by auch adoption. The adopted parents of such child shall inherit from said child under the statute of descent and distribution in the 
same way and manner as if the child has been born of lawful wodlock to the adopted parents; provided, howerer, if the adopted parents of the adopted child shall not survire the adopted child, then in that event the property of the deceased adopted child without lawful issue shall go to the natural parents in the line of descent and under the same provisions as are now or may hereafter be provided by law for descent and distribution; but in the erent that the adopted child without lawful 1ssue shall not be survired by either of its adopted or natural parents, then his property shall descend to his natural and adopted relatires, shere and share alike, according to Section 1393 of Carroll's Kentucky Statutes, 1936 Edition. such child shall be freod from all legal obligations of maintenance and obedience to such natural parents; provided, that where the adoptive parent of such child shall be married to one of the matural parents of such child, then the realation of such child towards such parent shall in no way be altered by such adoption, and the natural rights and obligations of such natural and adoptive parents towards such child shall be the same as if such child were the natural child of both the natural parent and the adoptive parent. Nothing herein shall be so construed as to prerent the adopted child from inheriting under the general law in regard to the descent and distribution fran its natural parents.

sec. 331b-9. A subsequent adoption is authorized by this act and in such a case the words "father, mother, or parent" Include father, mother, or parent by adoption.

sec. 331b-10. Secrecy as to court records.

The files and records of the court in the adoption proceedings 
shall not be open to inspection or copy by any person other than representatives of the State Department of Welfare, except upon order of the court expressly permitting inspection or copy. No person having charge of any birth or adoption records shall diselose the name of any adoptive parents appearing in such records or furnish any copy of any such records except upon order of the county court of the county in which the adoption took place.

Sec. 331b-11. Appeal to circuit from county court.

Any executor, administrator, guardian, trustee, or any person aggrieved by any order or judgment of the county court may appeal therefrom to the circult court within sixty days from the date of the judgment appealed from. The appeal of any minor fram an order of adoption may be taken by any person on his bebalf or by a guardian ad litem. In an appeal from an order of adoption if the child is a minor the State Department of Welfare shall be served with notice of such appeal. The State Board of Health, Buroau of Vital Statistles shall be notified if the adoption order is reversed.

Sec. 331b-12. In appeals to the circult court the appellant other than executor, adninistrator, guardian or trustee shall before his appeal be effectual file with the county court a bond in such sum with good surety as the judge thereof will approve to the effect that he will diligently prosecute his appeal to effect and pay all damages and costs which may be awarded against him, but no costs shall be awarded against any chlld, or person acting on behalf of a child, on appeal from such order of adoption. 
Sec. 33ib-13. No person, corporati on or association shall advertise in any newspaper that they will receive children for the purpose of adoption. No newspaper published in the Commonwealth of Kentucky or sold in the Commonwealth of Kentucky shall contain an adrertisement which solicits children for adoption, or the custody of children.

Sec. 33lb-14. Wherever the word "child" is used in this Act it shall include an adult unless the context otherwise required.

Sec. 331b-15. Any violation of Section 11 hereof shall be punishable by a fine of not less than $\$ 10.00$ nor more than $\$ 100.00$ or by confinement in the county jail for a period of not less than thirty days nor more than sixty days, or both fine and imprisoment. 
APPRWDIX II 
SUGGESTED OUTIINE FOR RRFPORT

TO THE COURT FOLLOWING INVESTIGATION

OI AN ADOPTION PHTITION

I. The Child

a. Date and place of birth

b. Longth of time in adoptire home

c. Circumstances of placement

(1) Authority to place obtained through

Comitiment by court

Surrender from parents

Request of parents (physician, hospital, friend, etc.)

Relative of child (mother, grandparents, otc.)

(2) By whom placed

(3) Date of placement

d. Physical condition

II. Natural Parents

a. Personal history (for both father and mother if parents married or $1 f$ paternity determined, otherwise for mother only)

(1) Name

(2) Marital status (1f married, date of marriage)

(3) Other children

(4) Present whe reabouts (if either parent is dead give date and cause of death; if parents are dirorced give date and place of divoree and disposition of child by court; if child was born out of wedlock and paternity determined show whereabouts of father and describe his attitude toward the child

(5) Nationality background

(6) Religion

(7) Bducation

(8) Mental status

(9) Physical condition

b. Reason for giving up the ohild 
III. Consent

IV. Petitioners

a. Relationship to the child

b. Residence

c. Personal history

(1) Date of marriage

(2) Religion

(3) Ago

(4) Nationality

(5) Education

(6) Montal and emotional stability

(7) Physical condition

d. Economic condition

(1) Occupation and earnings

(2) Home omership

(3) Insurance

(4) Other assets

- Community standing

f. Atmosphere of home

8. Other children - own or adopted and their att1tude toward child.

h. Motive for adoption

V. Adjustment of Child and Petitioners to Bach Other

VI. Recommendation of Agency Making Report 
APPINDIX III 
SUGGESTHD ADOPIION YATERTAI.

FOR ANT INDHPENDWNT PLACIMUENT

I. THE CHITD

a. Date and place of birth

b. Iongth of time in adoptive home

c. Circumstances of placement

(1) Authority to place obtained through

Coumitment by court

Surrender from parents

Request of parents (physician, hospital, friend, otc.) Relatives of child (mother, grandparents, etc.)

(2) By whom placed

(3) Date of placement

A. Health

Personal hygiene; dietary; appetite, amount and kind of exercise; sleoping arrangements, hours and somdness of sleep (eryout out; sleep walking). Does child enjoy using muscles? When he exerts himself in any way, does be begin to seem tired? How much rest or sleep does he seem to need before he is energetic again?

When tired, how does he show it - by restlessness, irritability, depression or sleeplessness?

Is he gaining in woight?

Modical eramination?

B. Adjustment to Foster Home

Family's Attitude

What is the family's attitude toward child? Does he feel himself to be "one of the famtly"? What is child's att1tude toward foster parents, brothers and sisters? Does ho talk froely with them about his school, his companions, his interests? Does he turn to them with any little worries? 


\section{Discipline}

What methods are used to prevent the child's repetition of an offense and what is child's reaction to punishment? Who does the punishing?

\section{Home Duties}

\section{Demands on Hin}

What are his home duties? Are they apecific and regular, or haphazard? Is patience exercised in teaching child, or is it assumed that he ought to know? Are his good points commended as well as his poor ones eensured?

\section{His Rosponse}

Are his duties performed willingly, well? Doss he grasp directions quickly and profit by them, or do instructions have to be repeated constantly? Hes he an allorranee? How does he use it? Is ho guided in its use?

\section{Play}

\section{Pacilities}

Is child encouraged to bring friends home? What recreation do foster parents provide in the home, gemes, toys, books, pets, etc.? What recreation do family and child have together? What oncouragement and assistance does he get in the use of the library? By whom? What kind of books does he read?

\section{His Response}

Does he seek or dread solitude? What are his resources for entertaiment when alone?

\section{Sex}

Is the child well dereloped physically? Has he matured and at what age? Is he attractive in face, figure and manners? To what degree does he appeer to erare petting and contact? Does he prefer friends of his own sex or otherwise? Are his friendships wholesome or fererish? What is his information on sex hyglene? If ho has none, who will give it to him? 
D. Adjustment to School

Situation

What grade is he in? If he is held back a grade, why? What course is he taking? And what are plans for further training? What is the attitude of pupils and teacher toward the child?

\section{Response}

Is his attendance regular; prompt; is it willing? What is his deportment? Does be dislike displine or revolt against school authority?

Special Abilities or Disabilities

What subjects interest him, and which does he dislike? Do any stir hin to spontaneous activities of thought or action? Has he shown talent for music, drawing, manual work?

F. Organized Actirities

Group Cantacts

What organized activities outside the home is he encouraged to join, e.8., clubs, scouts, Y.M.C.A.? Does he engage in competition and does he play the same games as other children his own age? Is he a member of a gang or group?

Social Traits

How readily does he make friends among either adults or children? Why? What kind of friends does be choose? of what age? What does he admire in people? What loyalty and permanence does ho show in Iriendship? Has he a chum? Is he a leader?

II. RATURAI PARBRTS

a. Personal history (for both father and mother if parenta married or if paternity determined, otherwise for mother only)

(1) Names

(2) Marital status (1f married, date of marriage)

(3) Other children

(4) Present whereabouts (if either parent is dead, give date and cause of death; if parents are dirorced, give date and place of dirorce and disposition of child by court; if child was born out of wodlock and paternity determined, show whereabouts (if possible) of father and describe his attitude toward child) 
(5) Nationality background

(6) Religion

(7) Fiucation

(8) Marital status

(9) Physical condition

b. Reasons for giving up the child

III. CONSENT

IV. PETITIONERS

a. Relationship to the child

b. Residence

c. Personal history

(1) Foster Home Report as now in use plus suggested. Items listed in "Outline for Report to Court"

(2) Verification of marriage

v. ADJUSTMENT OF CHILD AND PETITIONERS TO EACH OTHER

VI. RECOMAORNDATION OF AGEHCY MAKITNG REPORT 
APPIRDIX IV 
OUTLINE FOR RESEARCH

\section{THE CHIID}

NAME OF CHIID ........................... Male.... Female.... BIRTH DATE DATE OF ADOPIION PETITION DATE OF HEARING. DATE OF COURT RHPORT BIRTHPLACE: Name of County............ Outside of State

Maternity Home............ Om Home.

Not Given.

RRLATIONSHIP TO ADOPTIVE PARFNTS. None BY WHOM PLACED: Agency Parents.

Relative. Hospital

Physician. Minister.

Institution. Friend.

USE OF STUUY HONE: Length of Perlod

Name of Agency.

DATES OF PROBATION PERIOD. If extended, give reason. PHISICAI STATUS Source of Verification. MENTAL STATUS.

At Time of Placement. Psychological Findings and Source of. 


\section{NATURAL PARRANTS}

BIRTHPLACR: Mother. Father

MARITAL STATUS: At Time of Child's Birth.

At Time of Placement

OTHER CHITUREN.

Ages

RGASON FOK GIVING UP

CHIU FOK AUOPTION: Iconomic.

Prevented Mother Returning to Her Own Home

Incapacitation of Notber

Physical

Montal

Agency Active.

Remaris, Including Other Reasons

PHYSICAL STATUS OY MOIHGR.

Source of

NATIONATIIIT.

White

Negro

HEIIGION

Roman Catholic.

YORMAL EDUCATION OF MOTHER: Grades Under $6 \ldots \ldots$ Junior High.

Senior High.

College

Special Training.

OCCUPATION.

MBNTAL STAIUS: Below Average....... Average....... Superior.

Source of Psychological Findings.

IFGAI CONSIHN GIVEN BY: Mother.... Relative.... Orphanage.... Department of Public welfare..... Relinquisment of Parental Control

Iegal Conmitment. Without 


\section{PETITIONERS}

REHATIONSEIP TO CHIDD. None MARRIAGE DATE. Number of Years at Time of Placement. Adoption Remarks

AGE OF ADOPTIVE MOTHER.

OF ADOPTIVE FATHER. . OF CHID. ATE AT TDE OF PLACIMGNT:

Of Adoptive Mother...... Of Adoptive Father...... Or Child....... FORAAL EDUCATION: Adopt 1re Mother Adoptive rather

Grades 1 - 6

Junior High

Senior High

College

Speciel Training OCCURATION:

MEATAL STATUS:

Adopt1 ve Father. Adoptive Mother.

Source of Findings. PHYSICAL STATUS:

Adoptive Father Adoptire Mother.

Source of Tindings. BCONOMIC STATUS:

Annual Income. Home Owned. Buylng.

Renting Other Assets. COMMUITI STATUS. OTHLHR CHIIDREN IN ADOPTIVE HOME. Own. Others REMAARKS 
MOTIVE FOR ADOPTIOA

ANALYSIS OF RECOMMANDATION.

APPROVAL.

WITH RESERVATIONS

DISAPPROVAL

NEW BIRTH CHRTIFICATE

Secured.................... Not Secured

KNOWLEDGE OF PLACE OF ADOPTION

KNONN TO OWN PARHANT

AGENCY BNOWIIG CANDIDATE FOR ADOPTION BEFORE PLACEMMANT. 